\title{
Conceptualizing change in marine governance: Learning from Transition Management
}

*Christina Kelly, Geraint Ellis and Wesley Flannery

School of Natural and Built Environment, Queen's University Belfast. ckelly16@qub.ac.uk; g.ellis@qub.ac.uk; w.flannery@qub.ac.uk

* Corresponding Author

This is a pre-print version of a paper published in Marine Policy and should be cited as:

Kelly, C., Ellis, G. and Flannery, W. (2018) Conceptualizing change in marine governance: Learning from Transition Management, Marine Policy, 95, pp. 24-35.

Link to published version:

https://www.sciencedirect.com/science/article/pii/S0308597X17307480

\begin{abstract}
Coastal states are increasingly urged to transform their sectoral and fragmented marine governance regimes, and to implement integrated and holistic management approaches. However, to be successful, integrated governance mechanisms, such as marine spatial planning and ecosystem-based management, will involve transformative change of institutions, values and practices. Although 'integration' is commonly championed as an important normative attribute of marine management by academics, policymakers and environmental groups, it is often done so with little consideration of the complexity of institutional context in which a shift to new management approaches takes place. This paper reviews the most cited academic papers in the field of marine governance, showing that most overlook many of the key institutional challenges to integration, often derived from issues such as incumbency, path dependency, policy layering and other pragmatic strategies. While integrated management approaches have a normative capacity to fundamentally transform marine governance, the failure to understand the institutional dynamics that may impede effective implementation, leaves much of the research in this field naively impotent. There is a need, therefore, to develop a more realistic understanding of the context in which transformative change takes place. It is argued that Transition Management has the potential to both conceptualise and operationalise strategies to address these barriers based on a long term perspective using a participatory process of visioning and experimentation.
\end{abstract}

Key words: Transformative change; integrated marine governance; transition management 


\section{Introduction}

The sustainable management of marine resources is a pressing issue for coastal states, with growing emphasis being placed on the transformation of unsustainable governance regimes. The inefficiencies of longstanding marine management mechanisms are well-understood (Leslie and McLeod, 2007). Historically, marine governance has adopted a sectoral and fragmented approach. This approach has been unsuccessful in fostering the sustainable use of the marine environment, as it concentrates on governing individual industries separately from each other, failing to account for their interactions and cumulative impacts on ecosystems (Guerry, 2005). New, integrated and placed-based alternatives, such as ecosystem-based management $(\mathrm{EBM})$ and marine spatial planning (MSP), have been advanced as paradigmatically different approaches that can address issues arising from sectoral and fragmented management. There is growing evidence, however, that there is a gap between how these approaches are conceptualised in academic and policy literatures (Douvere and Ehler, 2007; Young et al., 2007; Douvere, 2008), and the complexity of the contexts in which they are practiced (Layzer, 2008; Scarff et al., 2015; Jones et al., 2016; Flannery et al., 2016).

It is believed that this gap derives from a poorly developed understanding amongst some marine scholars of how change happens, or fails to happen. Change processes encompass many issues including shifts in the values of society, adoption of new practices and institutional dynamics. In this paper the latter of these issues is concerning as the transformation of resource management is rarely facilitated through instant and wholesale governance changes, and existing, unsustainable institutions often persist after the adoption of new approaches. Institutions are understood here as "the cluster of rights, rules, and decision-making procedures that give rise to social practices, assign roles to participants in the practice, and guides interactions among occupants of these roles" (Young et al., $2008 \mathrm{p}$. xxii). Institutions impose form and consistency on human activities, foster expectations and the creation of societal norms and structure social action (Ostrom, 2014). Rather than reflecting on what institutional changes are necessary to effectively deliver on the promise of innovative approaches, implementation of new governance mechanisms is predominately facilitated within existing policy and institutional frameworks (i.e. the incumbent regime), often negating their transformative capacity. The institutional analysis literature illustrates that this approach to implementing governance transformation is beset by a number of well- 
recognised institutional issues, including, for example, policy layering, path dependency, institutional drift, and resistance by powerful actors.

Policy layering is a process, when transforming governance, through which new elements or functions are assigned to existing institutions (van der Heijden, 2011). Layering, through the addition of new policies, rules or agents, gradually changes the status and structure of institutions (Thelen, 2003). This may have negative impacts on the functioning of existing institutions by altering the logic of the institution or by compromising its capacity to deliver on its core competencies (Mahoney and Thelen, 2010). For example, Vince (2015) illustrates how Australia's Ocean Policy, a large scale attempt at developing integrated marine policy, ultimately failed as it adopted a policy layering approach which neglected the underlying issue of policy silos. Path dependency occurs in policy implementation when the reasoning underpinning governance transformation is focused on selecting options which most closely resemble existing practices or previous choices (Lindblom, 1959). Such path dependency tends to lead to incremental changes that may further frustrate the implementation of more radical approaches that are needed to address structural issues that lead to the reproduction of unsustainable management practices (Kirk et al., 2007). For example, Jentoft and Mikalsen (2004) argue that path dependency within Norwegian fisheries management created inevitable momentum towards quota transferability as, despite it not being the ultimate intention, it became embedded within various institutions and became difficult to resist. Institutional drift occurs when an institution fails to adapt to shifts in its environment (Streeck and Thelen, 2005). For example, institutional drift impeded the Great Barrier Reef National Marine Park Authority's capacity to effectively manage issues arising from the increased industrialisation and urbanisation of coastal Queensland (Morrison, 2017). Powerful actors within an existing institution or policy field may be resistant to new approaches which seek to alter the status quo. Transformation processes may then focus on incremental change, aimed at accommodating alterations that suit elites, rather than on contesting the systems and paradigms that give rise to the need for change in the first place (O'Brien, 2012). Flannery and Ó Cinnéide (2012) illustrate how momentum towards integrated marine management in Nova Scotia was resisted by powerful fisheries stakeholders, who used the nascent collaborative initiative to stall and delay progress.

These type of institutional dynamics are deeply rooted in prevailing societal structures (Rotmans and Loorbach, 2010), and if left unaddressed will continue to hamper attempts to 
radically change governance regimes in marine management as called for by the shift to holistic management. The institutional dynamics and realpolitik of implementing new management approaches is, however, under-theorised in the marine governance literature. It is therefore argued here that the main corpus of marine governance literature fails to fully grasp the institutional complexity and barriers that may undermine efforts to transform governance models, leaving much of the research in this field naively impotent.

This paper addresses this issue by highlighting Transition Management as having potential to provide both a more realistic conceptualisation of change and the capacity to guide its operationalisation. Transition Management is proposed as an alternative conceptual perspective to address the wider systems approach required for transformative marine governance, and which offers a way of operationalising this. Transitions represent system shifts between qualitatively different states and are explored and proposed as an alternative and more evolutionary approach to instigating transformation to more sustainable marine economies. Section 2 provides a critical review of highly cited marine governance literature from the perspective of transformative governance and institutional dynamics. The review focuses on understanding how transformative change is conceptualised in the marine governance literature and highlights a lack of engagement with issues concerning institutional change. The papers that do engage with such institutional dynamics illustrate the need for more critical engagement with a broad range of barriers that can impede the implementation of governance innovations. Section 3 explores the utility of Transition Management as an alternative approach to conceptualise and address these institutional barriers. Section 4 looks at applying a specific Transition Management approach to a marine context. The paper concludes by calling for a new type of marine governance research; one that is focussed on radical transformation and draws not just on strong conceptual models such as that of Transition Management, but also on change through research into, for, as and through practice.

\section{Institutional change and marine governance}

It is widely held that the sustainable management of marine resources demands the adoption of new integrated management approaches (Cantasano and Pellicone, 2014; Elliott, 2013; Gaspar et al., 2017; Kidd and Shaw, 2007; Lonsdale et al., 2015; McLusky and Elliott, 2004). Integrated management is often considered an appropriate response to pressing marine governance issues (e.g. degradation of marine ecosystems; addressing conflict arising from 
the increasing industrialisation of the marine environment etc.) and is offered as a way of overcoming current sectoral management approaches (Elliott, 2013; Holden, 2012; Kidd and Shaw, 2007; Margerum, 2011; Mitchell, 2005; Smith et al., 2011; Van Rijswick et al., 2014). The need to shift to integrated management is reflected in legislation, such as, Canada's Oceans Act and the EC Marine Strategy Framework and Maritime Spatial Planning Directives. Despite legislative support for the implementation of integrated management systems, there has been little consideration, or problematization, in the marine governance academic literature of the institutional challenges that could be faced in promoting the radical institutional change envisioned, such as the tenacity of sectoral problem framing or resistance from powerful incumbent interests. Indeed, and linked to this there does not appear to be an appreciation of whether applying the same rationalities of exploitation - in a more integrated way - will actually address the fundamental issues of sustainability that we face.

To illustrate this issue, the most cited articles in the Scopus database ${ }^{1}$ were reviewed, using search terms ': 'marine management' or 'marine governance' or 'marine planning' or 'marine spatial planning'. While it is acknowledged that some of these papers do not explicitly relate to issues of implementation, it is contended that they represent the corpus of the most prominent research in this field, with the greatest potential to influence normative thinking about marine governance. Each article was critically reviewed for reference to the transformation of governance regimes i.e. relating to wider institutional, legislative, social (behavioural and cultural) and political change. The results, summarised in Appendix A, indicate that 5 out of the 50 most cited articles referred to at least one of these transformative governance changes. These 5 articles, Rosen and Olsson (2013), Halpern et al. (2012), Glaser et al. (2010), Fidelman et al. (2012), and Österblom et al. (2010), consider some of the barriers to the type of institutional change required to establish more sustainable management regimes (see Table 1). These barriers include government inertia, power imbalances, lack of political commitment and a poor understanding of institutional behaviour and influences. While many of the most cited articles reviewed acknowledge the need for transformative

\footnotetext{
${ }^{1}$ See https://www.elsevier.com/solutions/scopus

${ }^{2}$ https://www.scopus.com/results/results.uri?sort=cpf\&src=s\&st $1=\% 22$ marine+planning $\% 22 \& s t 2=\% 22$ marine + management $\% 22 \&$ nlo $=\& n \mid r=\& n l s=\& s i d=8 d 04 a b b 35 a$ 15 cae8287f580e34d34f94\&sot=b\&sdt=cl\&cluster=scosubjabbr\%2c\%22SOCl\%22\%2ct\&sl=176\&s=\%28TITLEABS-KEY\%28\%22marine+planning\%22\%29+OR+TITLE-ABSKEY\%28\%22marine+management\%22\%29+OR+TITLE-ABS-KEY\%28\%22marine+governance\%22\%29+OR+TITLEABS-

$\underline{\text { KEY\% }} 28 \% 22$ marine+spatial+planning\%22\%29\%29+AND+DOCTYPE $\% 28 a r+O R+r e \% 29 \& c l=t \& o f f s e t=41 \&$ origin=r

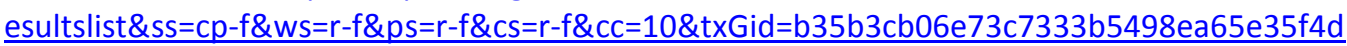


change (Crowder and Norse, 2008; Douvere, 2008; Day and Dobbs, 2013; Jackson, 1995; Plasman, 2008), they do not show an appreciation of the deep structural challenges of operationalising such transformation and as such, are poorly equipped to engage with effective strategies for change in institutional frameworks, values and practices to address these problems. For instance, MSP is described as an approach involving input, process, and output measures that can be used to manage human activities at sea (Ehler, 2008; Douvere, 2008; Gilliland and Laffoley, 2008), but unrelated to confounding issues such as institutional barriers, as MSP tends to focus only on the intervention of policies and processes within existing institutional arrangements. This oversight is neglected across the most cited marine governance literature, with the exception of the five selected articles which refer to some of the institutional barriers that progressive initiatives are confronted with but even here are dealt with in a cursory way. This continued failure of the main literature to understand and deal with the impact of such factors could result in unsustainable practices.

\section{[Insert Table 1 near here]}

Rosen and Olsson (2013) critically examine the formation of an international agreement to radically transform marine management in the Coral Triangle, a large-scale marine ecosystem located at the confluence of the Indian Ocean and the Western Pacific. They argue that current marine governance arrangements are often too fragmented to deal with dynamic ecosystems and cross-scale drivers of change, such as, overfishing, coastal development, pollution and climate change, and that there is a need to understand how transformative institutional change can be implemented (Rosen and Olsson, 2013). Their study highlights how networks of institutional entrepreneurs defined as "individuals and groups of individuals who leverage resources to create new institutions or transforming existing ones", can organise to overcome opposition to institutional change, such as government inertia and resistance by powerful stakeholders, and seize windows of opportunity to transform marine management (Rosen and Olsson, 2013, p.195). As the drivers behind marine resource degradation often transcend both policy sectors and nation-states, the ability to capitalise on windows of opportunities requires space, often created by institutional entrepreneurs, to mediate between political actors, sectoral stakeholders and community groups (Rosen and Olsson, 2013). The institutional entrepreneurs in the Coral Triangle had previous experience of working with marine conservation projects and were important in terms of providing 'social infrastructure' for exploring, managing and progressing the Coral Triangle initiative. 
They also had access to financial resources and networks to help scale-up niche ideas. This highlights the valuable contribution that grassroots initiatives can make towards helping and influencing local innovations, by identifying opportunities for change and exerting influence at the wider institutional level.

Through an expert workshop, Halpern et al. (2012) identifies near-term, science, policy and practice transformations needed to significantly advance MSP in the US. They identify a number of institutional challenges that may impede the effective implementation of MSP, including, a lack of political will, prioritisation of other objectives and a tendency to avoid institutional change until negative impacts directly affect social and economic well-being (Halpern et al., 2012). Like Rosen and Olsson (2013), Halpern et al. (2012) argue that the successful implementation of integrated management requires coordination and coherence across different governance scales. They argue that improving integration requires flexibility within governance agencies and an adaptive, learn-by-doing approach to MSP implementation. This indicates that a proactive approach to institutional change requires extra political motivation for planning and committing resources and a degree of willingness within existing agencies to adapt to the changing ecological, technological, social and political context.

Glaser et al. (2010) evaluate a community-based marine protected area (MPA) programme in Indonesia and found that, despite having an institutional structure designed to facilitate local participation, local knowledge about the MPA programme was very low and meaningful participation in decision-making was negligible for the majority of islanders. The implementation of the MPA programme was facilitated through a process of institutional change, which included the integration of MPA-related competencies into one government department. Glaser et al. (2010) found that informal coastal management institutions had developed outside, and in parallel, to the formal organisations of the programme. These 'bottom-up' informal experiments appeared more robustly anchored in local practices and norms and, in order to transform marine conservation governance in the area, needed to be better integrated into formal institutional frameworks (Glaser et al., 2010). These bottom-up or localised activities are influential in mediating a transition. They represent catalysts for change and are critical for challenging dominant paradigms and pioneering innovations in marine governance. 
Using the example of the Coral Triangle Initiative, Fidelman et al. (2012) highlight the diverse contextual factors that impede the sustainable governance of a large-scale marine commons. They contend that transformative interventions often underplay the relevance of existing institutions and their historical legacy in setting the context for governance reform and innovation. Fidelman et al. (2012) argue that poor understanding of, or regard for, existing institutions can lead to simplified judgements about resource systems, and, consequently, unsustainable management. They suggest that a more sustainable approach should incorporate experimentation and regular adjustments in accordance with the dynamic nature of marine socio-ecological systems (Fidelman et al., 2012). It is evident that innovation may be hindered by deeply embedded conventions borne out of historical institutional legacies and path dependency. It is suggested therefore that any type of transformative change in marine management should consider the need to go beyond previous choices and existing practice.

Exploring how to operationalise EBM in the Baltic Sea, Österblom et al. (2010) highlight the difficulty in altering existing multi-level regimes, which have formed to specifically manage individual sectors, and the need for stimuli to bring about institutional transformations. They highlight the role played by top-down incitements to regime transformations, such as the implementation of new EU directives or the accession of states to the EU, and local-level pilot projects and innovations in catalysing broader institutional change. While these impetuses can foster institutional transformation, Österblom et al. (2010) argue that the development of shared visions and mental models at the political level is fundamental for successful implementation of EBM. This requires leadership and communication skills as well as social and behavioural changes including: trust building, sense making and the linking of key individuals and partnerships. Institutional change should therefore allow for more interaction of top-down and bottom-up activities and between more mainstream individuals and radical or moderate innovators to allow for a cross-fertilisation of ideas and practices.

This review of the literature highlights the relatively limited way in which concepts of change and institutional dynamics are considered in the main corpus of marine management research. While there are a small number of papers that do discuss such issues, these do so in a way that often focusses on what are considered to be idiosyncrasies of individual cases and always in the absence of a broader conceptual understanding of how the normative ideas developed in academic work can be transferred into practice. This amounts to more than a weak 
understanding of the processes for effective knowledge exchange and points to a more fundamental failure of the marine literature to appreciate the social, political and institutional context in which marine management takes place and the impact of processes such as policy layering, path dependency, institutional drift and the influence of incumbent actors on resisting, diverting or slowing institutional change. It is therefore argued that there is a need for marine scholars to go beyond promoting normative models of sustainable governance and more critically engage with the specific processes that could bring about the transformative change many of them call for, and indeed, adopt new ways of undertaking research that is more committed to transformational change. As a way of promoting new ways of thinking about this problem, the concept of Transition Management is introduced in Section 3, followed by a review of how it could be applied to marine management in Section 4.

\section{Transition Management and Marine Governance}

The concept of sustainability transitions has largely emerged as a way of conceptualising, and fostering, shifts towards sustainable development and is concerned with the long-term process of radical and structural change at the level of societal systems (Grin et al., 2010; Loorbach and Rotmans, 2010; Rotmans et al., 2001; Van der Brugge et al., 2005). A key point here, is that this involves systemic change, going beyond sector-specific issues. As highlighted by Loorbach and Rotmans (2010, p.237) "this is the result of a much broader scientific development of transition research as an interdisciplinary field of study in which innovation studies, history, ecology and modelling are combined with sociology, political and governance studies and even psychology". In this context a 'transition' is defined as "a fundamental change in structure, culture and practices" (Rotmans and Loorbach, 2010, p.109), yet such transformations cannot be defined primarily on the basis of a definable end state but regarded as a process of redirecting and steering a wide range of factors (markets, energy technologies infrastructure, governance, individual behaviour) towards a more sustainable configuration. Transitions contain periods of slow and fast development as a result of positive and negative feedback mechanisms, and comprise "a gradual, continuous process typically spanning at least one generation (25 years)" (Rotmans et al., 2001, p17).

The interrelated, co-dependent and co-evolutionary character of modern societies and economies (especially under conditions of globalisation) means that decisions made at one policy sector affect other sectors, and form also complex negative and positive feedback loops among policy sectors and actors. This need for more holistic systems analyses and 
policies has become all the more necessary given that the increasing complexities of modern society have made it hard to predict consequences of policy actions (Taleb, 2012).

Transition Management has been developed into a governance model focussed on sciencepolicy collaboration and applied to areas such as water management (Bos and Brown 2012, Van Der Brugge et al., 2005), regional and city planning (e.g. Nevens et al., 2013), transport (Geels, 2012), tourism (Gössling et al., 2012), development (Jerneck and Olssen, 2008), healthcare (De Haan, 2010), and the science system (Schneidewind and Augenstein, 2012). Here, Transition Management has been deployed to better understand and operationalise change of large socio-technical systems. Core assumptions in transition theory include that: system innovation is required to address barriers to progress on environmental issues; change to complex social practice will take a long time; and a commitment to involve major social partners in defining and actualising transitions is necessary (Meadowcroft, 2005). A transition perspective therefore recognises the need for a system-wide approach in dealing with persistent problems and as such, could provide a fertile way to frame the context for the institutional transformation highlighted earlier in the paper. There are three important elements of a transition approach that can help understand how it can be applied to marine governance: multi-level, multi-stage and the process of Transition Management (Van der Brugge et al., 2005). Each of these are summarised in the following sections.

\subsection{Multi-level Perspective}

The Multi-level Perspective (MLP) distinguishes between three functional levels at which transition processes take place. These levels or contexts are referred to as niches, regimes and landscapes which have been used to distinguish between different forces for change in sociotechnical systems (Van der Brugge et al., 2005; Van Raak, 2015; Grin et al., 2010). The different functional levels are illustrated in Fig. 1. In a marine management context, the different functional levels at which a transition may take place have been conceptualised and described in Table 2.

[insert Fig.1 near here]

[Insert Table 2 near here]. 
The landscape level is influenced by 'external' forces such as changes in the macro economy, politics, population dynamics, natural environment, culture and worldviews. This level forms the wider context within which the regimes operate and responds to relatively slow trends and large-scale developments that play an important role in speeding up or slowing down a transition. It is beyond the direct influence of regime and niche actors (Meadowcroft, 2005; Van der Brugge et al., 2005; Van Raak, 2015). For example, climate change and ocean acidification are altering marine ecosystems requiring complex human responses, such as a range of technological, economic, communication and governance solutions (Mumby et al., 2017).

Regimes are dominant or prevailing practices, rules and patterns of institutions, assembled and maintained to perform economic and social activities (Avelino and Wittmayer, 2015; Foxon, 2013; Meadowcroft, 2005; Van der Brugge et al., 2005). Regimes are considered to be dynamically stable arrangements of dominant structures that shape the system. It is suggested that regimes do not easily change due to their heterogeneous elements which are highly interconnected resulting in a stable institutional, organisational, economic and cultural environment (Geels, 2004; Van der Voorn and Quist, 2016). This incumbency or institutional 'stickiness' was highlighted by Österblom et al. (2010) in their Baltic Sea study and, in particular, the difficulty in altering existing and stable multi-level regimes. These difficulties are reflective of historical institutional legacies such as path dependency and policy layering where implementing radical change is opposed and existing practices or the addition of new layers to existing regimes are favoured instead. The relationship between regime, actors and rules is fundamental in understanding regimes (Geels, 2004). As noted by Jørgensen (2012, p.998), "within regimes, actors are either rule-followers or game-players defined by the frames constituted by the regime". Therefore it is important to reflect on the rules or regulations as set down by the institutions and their rationale in terms of influencing the actions of actors embedded in them. As a regime shapes the socio-ecological system, it has a dominant position and is therefore associated with power. In transition studies, this power is primarily related to the regulative rules underlying the regimes and the 'power struggles' between incumbent regimes and upcoming niches (Avelino and Wittmayer, 2015).

Niches are localised areas where innovation can first take root and are comprised of individual actors, alternative technologies and local practices. Niches are important as they provide the seeds for change and are crucial for path-breaking innovations and overcoming 
path dependency (Geels, 2004; Geels and Schot, 2010; Smith and Raven, 2012; Van der Voorn and Quist, 2016). They represent spaces that are partially insulated or protected to allow for creativity and technological and social learning (Kuzemko et al., 2016; Smith and Raven, 2012). At the niche level, emerging visions or initiatives have the potential to challenge shortcomings in the dominant or prevailing paradigms of the regime. In a marine context, community initiatives and localised experiments in policy or practice could be considered examples of innovative initiatives or niches. Glaser et al. (2010) referred to community-led initiatives in Indonesia which have the potential to transform marine conservation practices and marine protected areas. These informal and formal bottom-up approaches represent types of niches in marine governance. Local initiatives, pilot studies, and research and development projects, are all types of experimental niches within the multilevel perspective of transitions. As Kuzemko et al. (2016, p.98) noted, niches can break through "if external landscape developments simultaneously create pressures on the regime that lead to cracks, tensions and windows of opportunity". An example of a niche breakthrough is the transition towards EBM of the Great Barrier Reef in Australia where the interplay among individual actors, organisations, and institutions at multiple levels was central to the transformation. This transformation was provoked by increased pressure on the Great Barrier Reef from terrestrial runoff, overharvesting, and global warming that triggered a new sense of urgency to address these challenges (Olsson et al., 2008) and avoid institutional drift.

The MLP therefore represents a useful conceptual framework to analyse the different forces of change, and the types of resistance that may be exerted upon them. Rosen and Olsson (2013) highlighted the need for institutional space, often created by entrepreneurs to negotiate between multi-levels of actors and stakeholders. In the MLP, niches symbolise spaces that are protected to allow for creativity and learning. Similarly, Glaser et al. (2010) noted the influence of 'bottom-up' and informal experiments in Indonesia as part of the MPA programme. These local initiatives represent niches involving local entrepreneurs acting as important stimuli in altering existing regimes and catalysing broader institutional change (Österblom et al., 2010). These stimuli are important factors in helping to overcome some of the institutional resistance highlighted previously in Sections 1 and 2 and the MLP provides the opportunity to consider how strategies for transformative change will need to respond to such barriers. 


\subsection{Stages of Transitions}

It has been proposed that transitions usually progress through four main phases that can be conceptualised as an S-shaped pattern (Verbong and Loorbach, 2012). This multi-stage concept is illustrated in Fig. 2. The first stage is described as a 'pre-development phase' of a dynamic equilibrium where the status quo does not visibly alter but changes take place under the surface. The second phase is defined as a 'take-off phase' in which, under sufficient pressure, thresholds are reached and the state of the system begins to shift and enter a reconfiguration or acceleration phase. The third phase enters an 'acceleration phase' where visible structural changes take place rapidly through an accumulation of socio-cultural, economic, ecological and institutional changes that reinforce each other. These changes are combined to form a new dominant regime that enters a fourth and final 'stabilisation phase' where the speed of social change decreases and a new dynamic equilibrium is reached (Van Der Brugge et al., 2005, p. 166; Verbong and Loorbach, 2012).

[insert Fig.2 near here]

The multi-stage concept frames regime change as a non-linear systemic shift, wherein largescale, fundamental changes occur over a long time (Verbong and Loorbach, 2012). It is also acknowledged that the S-curve, illustrated in Fig. 2, represents an 'ideal' transition whereby the system "adjusts itself successfully to the changing internal and external circumstances, while achieving a higher order of organisation and complexity" (Rotmans and Loorbach, 2010, p.127).

The initial pre-development stage in a transition is an important phase to overcome as there is a tendency for a 'business as usual' approach to result in increasing path dependence or in negligible change due to policy layering. This results in a 'lock-in', and practices and institutions become increasingly difficult to change (Schuitmaker, 2012). In the Coral Triangle Initiative, Fidelman et al. (2012) described how historical and existing institutional arrangements can hamper transformative interventions. Institutional problems often emerge from deeply embedded conventions constrained by previous decisions that create a path dependency. In this context, Fidelman et al. (2012) suggest that more experimentation and flexibility is required to adapt to dynamic marine ecosystems and avoid institutional drift. If, however, initiatives are not given the space and protection to flourish, they can potentially burn out, cause a system breakdown or backlash, and fail to progress beyond the 'take-off' or 'acceleration' stages of a transition (Rotmans and Loorbach, 2010). There is a real potential, 
therefore, for integrated governance processes that conform to existing regimes, and do not consider wider institutional dynamics, to stagnate and fail to instigate transformative marine governance.

\subsection{Transition Management}

The conceptual frame provided by the MLP, transitions and their multiple stages has been used to develop the innovative governance approach of Transition Management. Transition Management aims to facilitate and accelerate transitions through a participatory process of visioning, learning and experimentation (Grin et al., 2010; Loorbach and Rotmans, 2010; Rotmans et al., 2001). It is based on the coordination of multi-actor processes at different levels with the aim of achieving long-term sustainability through the creation of a joint problem perspective and long-term vision, developing innovation networks and fostering experimentation (Van der Brugge et al., 2005). Transition Management is anticipative and adaptive due to the complexity and uncertainty associated with transitions and deploys longterm thinking (at least 25 years) as a framework for shaping short-term policy, which is considered necessary when dealing with such uncertainty and allows for incremental change. Transition Management emphasises multi-domain, multi-actor and multi-level thinking in order to address the complexities involved when working with a multitude of sectors and actors across a range of different scale levels. A focus on learning and a special learning philosophy i.e. learning-by-doing and doing-by-learning, is another important characteristic of Transition Management. An anticipative and adaptive approach is required, particularly when trying to bring about system innovation alongside system improvement. Therefore, Transition Management highlights the need to keep a large number of options open to allow for flexibility and adaptability over a longer period of time (Rotmans et al., 2001).

A core purpose of Transition Management is to influence the direction and speed of the change dynamics in contributing to end goals such as sustainability. The Transition Management approach was introduced into a policy setting within the Netherlands Fourth National Environmental Policy Plan (NMP4) in 2001, where it pioneered important extensions in "an attempt to reinvigorate ecological modernisation" (Smith and Kern, 2009, p.78). By embracing complexity and uncertainty as opportunities, transitions can be provided with an initial impetus, supported and accelerated.

[insert Fig. 3 near here] 
Transition Management is an iterative governance framework which is cyclical and holistic. A typical management cycle is illustrated in Fig. 3. The Transition Management cycle comprises different activities coinciding with four key stages (Loorbach and Rotmans, 2010; Van der Brugge et al., 2005; Wittmayer et al., 2014). Stage 1 involves problem structuring, envisioning and establishing new paradigms, driven by a small 'Transition Team' assembled by a sponsoring organisation. This stage is concerned with structuring the problem in question, developing a long-term sustainability vision and establishing a Transition Arena of key individuals who grasp the needs for fundamental change. Institutional barriers such as path dependency and institutional drift could feature within the problem framing exercise and be highlighted for further analysis. In stage 2, future images are developed, the transition agenda is set and transition paths are derived. During this stage coalitions are also formed and policy is deliberated. This stage represents a good opportunity to address issues such as policy layering and altering the logic of the institutions involved. The third stage involves niche and project experimentation which encourages ideas and actions that change mind sets. The fourth and final reflexive stage involves monitoring, evaluation and learning from the transition experiments, and making adjustments in the vision, agenda and coalitions based on these outcomes.

The four stages make it possible to explore different strategies such as "participant selection, framing the specific transition challenge, type of process needed, use of different types of policy and process instruments" (Loorbach and Rotmans, 2010, p.239) along with providing adequate flexibility and adaptability to address persistent institutional problems through continued reflexivity and re-adjustment.

Providing space for innovation and the creation of new coalitions, partnerships and networks within transition arenas, will be important considerations in the development of potential solutions towards integrated marine governance. As stipulated by Österblom et al. (2010), the development of shared visions and mental models, as well as social and behavioural changes including trust building and linking of partnerships, are necessary for institutional transformation and could be facilitated through a Transition Management approach.

As shown in Fig. 3, a key stage in Transition Management is to establish a 'Transition Arena' which facilitates interaction, knowledge exchange and learning between key actors (Kemp and Loorbach, 2006) or 'change-agents'. By enhancing a broadening network of actors that 
can share and drive the vision, thinking and actions, it can provide a framework for the emergence of innovation and potentially, pioneering niches. This is an important consideration for transitions within a marine context, particularly when building on the work of existing 'bottom-up' initiatives or local niches and addressing issues of resistance to change from powerful actors.

While transition processes are challenging, the frame does provide a way to conceptualise how change can be progressed, and thus potentially overcoming some of the failures of marine management literature highlighted in Section 2. Although each transition context will differ, there are generic steps (see Table 3) which can help to guide the process, which can be adopted within the field of marine management.

The early steps in the Transition Management process will be key to ensuring the successful involvement of a diverse range of participants. For example, the Transition Team ideally would comprise researchers/ individuals who are able to understand system-wide challenges and diagnose the nature of persistent problems, and then begin to drive change. This team would, through system and actor analyses, identify and select engaged citizens or change agents to form the transition arena, who reflect the diversity of the local area and are not necessarily representative of the predominant political or institutional system. In a marine context, it will be important to create a Transition Arena that involves those focussed on change from a variety of perspectives including local citizens, social enterprises, marine scientists as well as the usual government departments, agencies, local authorities, private sector organisations and interested bodies. The dynamic and complex nature of marine ecosystems may give the impression that marine management is for experts only. The majority of coastal citizens and organisations however, make decisions every day that influence the future of their seas and therefore have a role to play as a decision-maker and contributor from their own position and perspective. Van Der Brugge et al. (2005, p.174) emphasised this point also in their transitions example when they suggested that selected participants should join on a personal account "to avoid a rather narrow focus on the shortterm stakes and vested interests of their occupational background". Therefore, representatives from government departments and agencies need to interact with change agents and the process despite being associated with the dominant system.

Rotmans et al. (2001) observed that the role of government was different in each phase of the transition process. In the pre-development stage of a transition, the government would act as 
a catalyst and director by maintaining a wide playing field and organising and stimulating discussions with other actors. During the take-off stage, the government would mobilise actors in the direction of the transition objective, and in the acceleration stage they should stimulate learning processes about possible solutions by helping to draw up an agenda, form communal visions, create niches and anticipate actors' interests. In the final stabilisation stage, the government would provide guidance on stabilising the system, preventing or containing backlashes and other negative effects i.e. act as controller and consolidator. This is an important consideration in marine management when in the past, local initiatives such as the Coastal Partnerships in the UK, never developed beyond the pre-development stages due to inter alia a lack of sustained government support (Stojanovic and Barker, 2008).

There are also limitations and boundaries to the role of government in a transition which include external or landscape factors such as climate change and cultural values, over which the government has limited influence. The ability of national, regional and local governments to interact with local stakeholders or niche actors and players may also be dependent on political anchorage i.e. the involvement of local, regional and national politicians. Political anchorage ensures governance networks including informal, coastal groups and bottom-up initiatives talk to government (Hovik and Hanssen, 2016). Alternatively, if this integration is not achieved, there is a risk that these networks will be excluded from the formal system of government. It is important therefore to consider the role of arenas, power-holders and in particular, governments and political anchorage within any transition process.

This paper has highlighted the limited way in which the main corpus of marine literature has conceptualised institutional change and then introduced the concept of Transition Management as a useful frame for addressing this gap in understanding, and offering a way in which this could be operationalised. The potential of using a Transition Management approach and its contribution to marine management is explored in Section 4.

\section{Applying a specific Transition Management approach to a marine context}

The transitions approach is still being developed and several different approaches have been co-evolving (Grin et al., 2010). To date, transition perspectives have been applied to the water, health, energy and other sectors however, there has been little engagement with the concept in terms of marine management. However, the transitions paradigm has been identified as a possible perspective to address the problems associated with long-term sustainability and marine governance. 
Following a review of a number of examples of Transition Management practice, Kelly (2017) initiated a debate on how this could be applied to marine challenges through the adoption of a number of core processes namely; (i) forming a coastal transition team and conducting a system and actor analysis; (ii) based on the actor analysis, establishing a coastal transition arena group; (iii) framing the transition challenge; (iv) creating visionary images for the future of coastal management; (v) developing transition pathways indicating changes and actions needed to reach an envisioned future; and publishing these as part of a transition agenda in accordance with the coastal transition arena; (vi) publishing the agenda and engaging with the public to adopt and adapt the actions; and (vii) initiating transition experiments in line with the transition agenda to deliver sustainable integrated management of coasts. Through these core processes and stages, it is suggested that a Transition Management approach could offer a way of addressing the lack of perspective on institutional change and systemic transformation in marine governance research.

A specific and potential Transition Management approach to marine governance has therefore been crafted based on the literature review and review of Transition Management examples in practice. This approach seeks to develop innovation networks of change-agents and entrepreneurs with an ambitious agenda of reform for marine management. This could commence with tangible breakthrough projects, similar to 'grassroots' and 'bottom-up' MPA projects (Glaser et al., 2010; Rosen and Olsson, 2013). It is important to build up a broadening network of diverse actors that understand the need for fundamental change and are prepared to engage in 'risky' experimentation. This type of approach acknowledges the potential of individual coastal management initiatives contributing to a wider Transition Arena and a network of actors. The stages and recommended actions outlined in this approach are summarised in Table 4.

[Insert Table 4 near here]

At the heart of this approach is a radical process of visioning, engagement, learning and experimentation, evaluation and reflexivity. This facilitates a better understanding of the different dynamics of change and the inter-dependencies between multiple actors, levels and sectors.

With regards to envisioning, Transition Management concentrates on a long-term vision with the main dimensions of sustainability for the system under focus. It is important to 
acknowledge that whilst inspiring visions can mobilise actors they are often too idealistic or even utopian to achieve and therefore unrealistic (Verbong and Loorbach, 2012). Nevertheless, from a review of watershed management in the Lower Mississippi River (Van der Voorn and Quist, 2016), it was documented that emerging visions had an important role to play in guiding a transformation. In the proposed Transition Management approach, a technique called 'backcasting' is included in the envisioning stage which involves actors identifying the steps to be taken first before a particular pathway can be chosen to reach their end goal (Neuvonen et al., 2014). It is therefore worth considering carefully the pathways towards these end states rather than just the end states themselves. The aim is to devise future-oriented strategies that go beyond business-as-usual solutions. In a marine context, this could involve asking transition arena participants to formulate fundamental changes in a "from - to" format. For example: "from centralised to decentralised policy development" or "from port/harbour-related industries to renewable energy hub" and clustering these in a group discussion. Following identification of pathways, the arena group prioritises the ones they consider most important and personally motivating. The arena group establishes a transition agenda which summarises the transition challenge, visionary images, pathways and short-term actions.

In terms of engagement, the transition agenda is an initial step for a wider group of people, organisations and initiatives to embrace aspirations for improved marine governance and sustainability. The agenda enables others to link this ambition with their own agendas and practices. The engagement phase could be launched with an event, where the arena members introduce the transition agenda to participants of their own networks and associates. Engagement with a wider network will increase the impact of the arena results and explore the potential of others to contribute to marine sustainability. Maritime festivals and events are becoming increasingly popular and include nature workshops for families, guided walks and restoration activities like coastal clean-ups (Stojanovic and Barker, 2008). In Ireland, Seafest ${ }^{3}$ coincides with the annual Our Ocean Wealth Summit and raises awareness of the value and opportunities provided by the sea and celebrates maritime heritage. These activities help to attract further interest, expertise and resources.

The learning and steering stage of this approach encourages transition experiments to trial alternative or innovative structures, cultures and practices. Nayak and Armitage (2018) report

\footnotetext{
${ }^{3}$ http://seafest.ie/en/about/
} 
that in the Tam Giang lagoon, Vietnam, impacts from increased aquaculture, capture fisheries and near-shore development have led to catch reduction, disease outbreaks and declining water quality. This has triggered a range of coping efforts involving innovative practices such as: novel use of spatial use rights; shifts away from top-down governance arrangements; participatory planning efforts involving diverse actors and resource user groups in management and decision making; and policy changes to land and fisheries management, which have all played a significant role in the formation of co-management institutional networks that contribute to trust building and learning (Nayak and Armitage, 2018). Similar experiments could provide potential options for exploration and experimentation within the medium term phase of the Transition Management approach.

In the case of collaborations, working groups can be established to work on initiatives or experiments and for recruiting the relevant competences and resources. If required, new actors can be invited to expand on themes and activities not addressed by the emerging working groups. Collaborative processes of knowledge sharing and co-production can help to surmount imbalances in power and address issues of equity more explicitly.

The evaluation phase examines what has been achieved in terms of content, process dynamics and knowledge. The actors who take part in the transition process evaluate transition objectives and goals, the transition process itself and the transition experiments. Reflecting on activities and their coherence with the transition agenda can help to draw lessons and explore the gradual adjustment of existing development pathways in light of uncertain conditions and long-term goals. Reflexivity also involves a recognition of power issues which can obstruct integration and are usually embedded in existing institutions and divisions where unequal power dynamics can exist between different actors at different scales. In marine management, Flannery et al. (2018) provide empirical evidence of exclusion and non-participation of stakeholders in marine spatial planning which is having negative impacts on its much anticipated potential and democratic legitimacy. It is therefore fundamental within this proposed phase of monitoring, evaluation and reflexivity that existing modes of thinking and acting, as well as social structure are critically scrutinised. This enables innovative and radical suggestions such as policy proposals and novel institutional settings to co-evolve, gradually leading to institutional transformation.

The proposed approach will inevitably have some limitations in terms of addressing marine governance challenges. It is not possible to forecast the course of a transition in marine 
management, only create an opportunity or an impulse towards a more sustainable system. Transition Management can however, be used as a mechanism to recognise the various phases of change and recommend distinct actions for coordinated management. It is not a definitive design and will have to be tailored to address specific geographical circumstances and emerging socio-economic, political and environmental conditions throughout the process. This may exasperate participants but adequate time will be needed for ideas to evolve, trust to develop and conditions to change.

\section{Conclusion: Transition Management, institutional change and marine management}

Marine ecosystems are being degraded by unsustainable anthropogenic activities that are managed in a fragmented manner that does not adequately take into account user-user and user-environment interactions, conflicts and cumulative impacts. As this approach to marine management fails to arrest environmental degradation, researchers, international legislation and policy drivers are increasingly calling for better integration through processes such as MSP and EBM. Although there is a broad consensus around many of the key normative features of sustainable management of the marine environment, there have been major challenges when attempting to transfer these into practice. There are far-reaching and interdependent reasons for this, with the complexity of the institutional context in which marine management takes place, being an important factor. Issues such as path dependency, policy layering, institutional drift and the resistance of powerful actors are often neglected by the academic literature on marine management. As shown by the review discussed earlier in Section 2, only a small number of the most cited papers acknowledge the governance challenges to sustainable management and engage with some of the institutional barriers that progressive initiatives are confronted with. Although these issues tend to be discussed in a context of individual case studies rather than a broader conceptual model for institutional change, they do highlight the critical importance of factors including entrepreneurial activities, bottom-up and informal experiments, top-down and external pressures and institutional flexibility and adaptability in catalysing change. A continued failure to understand the negative impact of institutional dynamics and an inability to design effective strategies for change, results in the reproduction of unsustainable practices and continued environmental degradation. It has been suggested in this paper that Transition Management has the potential to address some of these issues by; i. providing a conceptual framework for understanding the factors that can drive (or slow down) systemic change; and ii. providing a 
framework for operationalising change through the activities of a Transition Team, a Transition Arena and processes of experimentation and network development.

In terms of a conceptual framework for understanding change, Transition Management has great value in that it $\underline{i s}$ a theory of change with transitions being a long-term process of radical transformation of structures, cultures and practices. Transition Management is therefore based on the assumption that change is needed and focussed on the ways in which this is inhibited or facilitated - rather than the starting point of much marine governance research which only focusses on desirable end states and not the processes of realising them. Furthermore, Transition Management is based on a systems view and attempts to encompass all the complex issues that may influence the transformation of a policy area rather than focusing on individual elements of it. In marine management this relates to taking account of the complexity and interlinkages of different users and uses and to a broadening of an initial narrow focus e.g. sustainable resources. The MLP helps to analyse the interactions and linkages at different levels within a marine context. For example, external pressures such as the global economy have been driving the 'blue growth' agenda which has dominated MSP. This is having adverse impacts on the ecological integrity of the marine ecosystem. Transition Management focuses on a shift in the current way of doing or thinking i.e. from more economic-related outcomes to a broader concept of sustainability, which emphasises environmental, social and economic wellbeing and prosperity. This will involve building upon societal dynamics, and more collaboration across organisations other than marine and environment-oriented, and increased reflexivity.

As noted in this section, this approach not only has the benefit of conceptualising change, but through Transition Management also suggests the concrete steps for initiating and managing change. Drawing on its analysis of the factors that can be critical in catalysing change, Transition Management offers a number of adaptable generic steps that can be used to guide a transition in marine management (e.g. establishing a transition team and arena; envisioning etc.) based on principles of experimentation and learning which facilitates different levels of interplay involving multiple actors, levels, stages and power relations with the aim of achieving long-term sustainability. This process can help to address the difficulties outlined in the marine literature review discussed in Section 2. For example, the Transition Arena represents an alternative platform to explore transition politics and priorities, different actors and their roles and understand shifting power relations and resistance to change as described by Halpern et al. (2012). There is the potential to confront issues of path dependency and 
power through shared problem framing. The experimentation stage in particular, encourages radical short-term actions, guided by a long term perspective for system restructuring. This experimentation phase is important for questioning mind-sets and allowing ideas and actions that go against the current. By exploring different options, a degree of flexibility is realised which is necessary for achieving integration (Halpern et al., 2012), avoiding institutional drift and dealing with uncertainty and complexity in marine governance. It is argued, therefore, that a framework based on Transition Management offers a valuable approach towards addressing inhibiting institutional dynamics associated with marine management.

Finally, to understand whether a transition approach to management could live up to this potential, it is important that the adoption of new conceptual frameworks, and practice of innovative governance experiments is accompanied by marine governance research that effectively engages with the issues highlighted in this paper. Although there is scope for a dedicated research agenda on marine transitions, many of the key questions to be addressed have been previously highlighted in critical commentaries: for example Flannery et al. (2016) have called for a need to understand the distributional impacts and role of power in marine spatial planning, which would help understand the control exerted by incumbent actors and the political outcomes of current unsustainable practices. Similarly, Kidd and Ellis (2012) have called for a more phronetic approach to research in marine management, which echoes the transition call for learning-by-doing and doing-by-learning, while also highlighting the factors that contribute to successful implementation and the impacts of new institutional design. Equally, Morrissey and Heidkamp (2018) contend that the spatial dimension has been lacking in transitions research so far. They suggest a sustainability transitions perspective should encompass an explicitly spatial focus to interrogate sustainability challenges within the coastal zone. It will be of particular importance for researchers to contribute to and offer a critical analysis of experiments in marine transition arenas and the evaluation of those initiatives that have potential to be nurtured as niche opportunities which could address the institutional inertia that currently blunts the implementation of novel governance frameworks. Indeed, it is only through a more engaged system analysis that the barriers that inhibit the transition to sustainable marine management can be fully understood and addressed and transformative governance can be effectively implemented.

\section{Acknowledgements}


The authors wish to thank the Environmental Protection Agency Ireland for supporting this research, as part of the funded IMMERSE project (Ref: 2013-B-PhD-11). Thanks also to the Editor-in-Chief and anonymous reviewer for providing comments on this manuscript. 


\section{References}

Avelino, F. and Wittmayer, J. M. (2015). Shifting Power Relations in Sustainability Transitions: A Multi-actor Perspective. Journal of Environmental Policy and Planning, 1-22. DOI:10.1080/1523908X.2015.1112259

Bos, J.J. and Brown, R.R. (2012). Governance experimentation and factors of success in socio-technical transitions in the urban water sector. Technological Forecasting and Social Change, 79(7), 1340-1353.

Cantasano, N. and Pellicone, G. (2014). Marine and river environments: A pattern of Integrated Coastal Zone Management (ICZM) in Calabria (Southern Italy). Ocean \& Coastal Management, 89(0), 71-78. DOI: http://dx.doi.org/10.1016/j.ocecoaman.2013.12.007

Crowder, L and Norse, E. (2008). Essential ecological insights for marine ecosystem-based management and marine spatial planning. Marine Policy, 32(5), 772-778. DOI: 10.1016/j.marpol.2008.03.012

Day, J.C. and Dobbs, K. (2013). Effective governance of a large and complex crossjurisdictional marine protected area: Australia's Great Barrier Reef. Marine Policy, 41, 14-24. DOI: 10.1016/j.marpol.2012.12.020

De Haan, J. (2010). Towards Transition Theory. DRIFT (Dutch Research Institute for Transitions), Faculty of Social Sciences. Rotterdam, Erasmus University Rotterdam (Ph.D. Thesis).

Douvere, F. (2008). The importance of marine spatial planning in advancing ecosystem-based sea use management, Marine policy, 32(5), 762-771

Douvere, F. and Ehler, C. N. (2007). International Workshop on Marine Spatial Planning, UNESCO, Paris, 8-10 November 2006: A summary. Marine Policy, 31(4), 582-583. DOI: 10.1016/j.marpol.2007.02.001

Ehler, C. (2008). Conclusions: Benefits, lessons learned, and future challenges of marine spatial planning. Marine Policy, 32 (5), 840-843. DOI: 10.1016/j.marpol.2008.03.014 
Elliott, M. (2013). The 10-tenets for integrated, successful and sustainable marine management. Marine Pollution Bulletin, 74(1), 1-5. DOI:10.1016/j.marpolbul.2013.08.001

Fidelman, P., Evans, L., Fabinyi, M., Foale, S., Cinner, J. and Rosen, F. (2012). Governing large-scale marine commons: Contextual challenges in the Coral Triangle. Marine Policy, 36(1), 42-53. DOI: 10.1016/j.marpol.2011.03.007

Flannery, W., Ellis, G., Ellis, G., Flannery, W., Nursey-Bray, M., van Tatenhove, J. P. M., Kelly, C., Coffen-Smout, S., Fairgrieve, R., Knol, M., Jentoft, S., Bacon, D. and O’Hagan, A.M. (2016) Exploring the winners and losers of marine environmental governance/Marine spatial planning: Cui bono?/“More than fishy business": epistemology, integration and conflict in marine spatial planning/Marine spatial planning: power and scaping/Surely not all planning is evil?/Marine spatial planning: a Canadian perspective/Maritime spatial planning "ad utilitatem omnium"/Marine spatial planning: "it is better to be on the train than being hit by it"/Reflections from the perspective of recreational anglers and boats for hire/Maritime spatial planning and marine renewable energy, Planning Theory \& Practice, 17 (1), 121-151, DOI: $10.1080 / 14649357.2015 .1131482$

Flannery, W., Healy, N. and Lunab, M. (2018). Exclusion and non-participation in Marine Spatial Planning. Marine Policy, 88, 32-40. DOI: 10.1016/j.marpol.2017.11.001

Flannery, W. and Ó Cinnéide, M. (2012). Deriving lessons relating to marine spatial planning from Canada's eastern Scotian shelf integrated management initiative. Journal of Environmental Policy \& Planning, 14(1), 97-117.

Foxon, T. J. (2013). Transition pathways for a UK low carbon electricity future. Energy Policy, 52, 10-24. DOI:10.1016/j.enpol.2012.04.001

Foxon, T. J., Hammond, G. P. and Pearson, P. J. G. (2010). Developing transition pathways for a low carbon electricity system in the UK. Technological Forecasting and Social Change, 77(8), 1203-1213. DOI:10.1016/j.techfore.2010.04.002 
Frantzeskaki, N. and De Haan. (2009). Transitions: two steps from theory to policy. Futures, $41(9), 593-606$.

Gaspar, R., Marques, L., Pinto, L., Baeta, A., Pereira, L., Martins, I., Marques, C. and Neto, J. M. (2017). Origin here, impact there-The need of integrated management for river basins and coastal areas. Ecological Indicators, 72, 794-802. DOI:10.1016/j.ecolind.2016.09.013

Geels, F. W. (2004). From sectoral systems of innovation to socio-technical systems Insights about dynamics and change from sociology and institutional theory. Research Policy, 33(67), 897-920. DOI:10.1016/j.respol.2004.01.015

Geels, F.W. (2012). A socio-technical analysis of low-carbon transitions: introducing the multi-level perspective into transport studies. Journal of Transport Geography, 24, 471-482.

Geels, F. W. and Schot, J. (2010). The dynamics of transitions: A socio-technical perspective. In Grin, J., Rotmans, J. and Schot, J. (Eds.), Transitions to Sustainable Development. New directions in the study of long term transformative change. New York: Routledge (pp. 11)

Gilliland, P.M. and Laffoley, D. (2008). Key elements and steps in the process of developing ecosystem-based marine spatial planning. Marine Policy, 32 (5), 787-796. DOI: 10.1016/j.marpol.2008.03.022

Glaser, M., Baitoningsih, W., Ferse, S. C. A., Neil, M. and Deswandi, R. (2010). Whose sustainability? Top-down participation and emergent rules in marine protected area management in Indonesia. Marine Policy, 34(6), 1215-1225. DOI: 10.1016/j.marpol.2010.04.006

Gössling, S., Hall, C.M., Ekström, F., Engeset, A.B. and Aall, C. (2012). Transition management: A tool for implementing sustainable tourism scenarios? Journal of Sustainable Tourism, 20(6), 899-916.

Grin, J., Rotmans, J. and Schot, J. W. (2010). Transitions to Sustainable Development. New Directions in the Study of Long Term Transformative Change. New York: Routledge 
Guerry, A. D. (2005). Icarus and Daedalus: Conceptual and tactical lessons for marine ecosystem-based management. Frontiers in Ecology and the Environment, 3(4), 202-211.

Halpern, B. S., Diamond, J., Gaines, S., Gelcich, S., Gleason, M., Jennings,S., Lester, S., Mace, A., McCook, L., McLeod, K., Napoli, N., Rawsonm, K., Rice, J., Rosenberg, A., Ruckelshaus, M., Saier, B., Sandifer, P., Scholz, A. and Zivian, A. (2012). Near-term priorities for the science, policy and practice of Coastal and Marine Spatial Planning (CMSP). Marine Policy, 36(1), 198-205. DOI:10.1016/j.marpol.2011.05.004

Holden, M. (2012). Is Integrated Planning Any More Than the Sum of Its Parts?: Considerations for Planning Sustainable Cities. Journal of Planning Education and Research, 32(3), 305-318. DOI:10.1177/0739456X12449483

Hovik, S. and Hanssen, G. S. (2016). Implementing the EU Water Framework Directive in Norway: Bridging the Gap Between Water Management Networks and Elected Councils? Journal of Environmental Policy and Planning, 18(4), 535-555. DOI:10.1080/1523908X.2016.1149049\#

Jackson, S.E. (1995). The water is not empty: Cross-cultural issues in conceptualising sea space. Australian Geographer, 26 (1), 87-96. DOI: 10.1080/00049189508703133

Jentoft, S. and Mikalsen, K.H. (2004). A vicious circle? The dynamics of rule-making in Norwegian fisheries. Marine Policy, 28(2), 127-135.

Jerneck, A. and Olsson, L. (2008). Adaptation and the poor: development, resilience and transition. Climate Policy, 8(2), 170-182.

Jones, P.J., Lieberknecht, L.M. and Qiu, W. (2016). Marine spatial planning in reality: Introduction to case studies and discussion of findings. Marine Policy, 71, 256-264. https://doi.org/10.1016/j.marpol.2016.04.026

Jørgensen, U. (2012). Mapping and navigating transitions-The multi-level perspective compared with arenas of development. Research Policy, 41(6), 996-1010. DOI:10.1016/j.respol.2012.03.001 
Kelly, C. (2017). Towards the Integrated Management of Irish Estuaries and Coasts: Proposing an 'Integration Transition Pathway' using a multi-level perspective. Unpublished Doctoral Thesis. Queen's University Belfast.

Kemp, R. and D. Loorbach, D. (2006). Transition management a reflexive governance approach, In Voss, Bauknecht and Kemp (Eds.), Reflexive Governance for Sustainable Development. Edward Elgar Publishing.

Kidd, S. and Ellis, G., 2012. From the land to sea and back again? Using terrestrial planning to understand the process of marine spatial planning. Journal of Environmental Policy \& Planning, 14(1), 49-66.

Kidd, S. and Shaw, D. (2007). Integrated Water Resource Management and Institutional Integration: Realising the Potential of Spatial Planning in England. The Geographical Journal, 173 (4), Critical Perspectives on Integrated Water Management, 312-329. DOI:10.1111/j.1475-4959.2007.00260.x

Kirk, E.A., Reeves, A.D. and Blackstock, K.L. (2007). Path dependency and the implementation of environmental regulation. Environment and Planning C: Government and Policy, 25(2), 250-268.

Kuzemko, C., Lockwood, M., Mitchell, C. and Hoggett, R. (2016). Governing for sustainable energy system change: Politics, contexts and contingency. Energy Research and Social Science, 12, 96-105. DOI:10.1016/j.erss.2015.12.022

Layzer, J. A. (2008). Natural experiments: ecosystem-based management and the environment, Cambridge, MA: The MIT Press.

Leslie, H.M. and McLeod, K.L. (2007). Confronting the challenges of implementing marine ecosystem-based management. Frontiers in Ecology and the Environment, 5(10), 540-548.

Lindblom, C.E. (1959). The Science of "Muddling Through", Public Administration Review, 19(2), 79-88. 
Lonsdale, J., Weston, K., Barnard, S., Boyes, S. J. and Elliott, M. (2015). Integrating management tools and concepts to develop an estuarine planning support system: A case study of the Humber Estuary, Eastern England. Marine Pollution Bulletin, 100 (1), 393-405. DOI:10.1016/j.marpolbul.2015.08.017.

Loorbach, D. and Rotmans, J. (2006). "Managing transitions for sustainable development" in X. Olshoorn and A.J. Wieczorek (eds.) Understanding Industrial Transformations: Views from Different Disciplines, Dordrecht: Springer.

Loorbach, D. and Rotmans, J. (2010). The practice of transition management: Examples and lessons from four distinct cases. Futures, 42(3), 237-246. DOI:10.1016/j.futures.2009.11.009

Mahoney, J. and Thelen, K. (2010). A Theory of Gradual Institutional Change, In Mahoney, J. and Thelen, K., (Eds) Explaining institutional change: Ambiguity, agency, and power. Cambridge: Cambridge University Press. pp1-37.

Margerum, R. D. (2011). Beyond Consensus: Producing Results from Collaborative Environmental Planning and Management. Cambridge, MA, USA: MIT Press.

Meadowcroft, J. (2005). Environmental political economy, technological transitions and the state. New Political Economy, 10(4), 479-498. DOI:10.1080/13563460500344419

McLusky, D. S. and Elliott, M. (Eds.). (2004). The estuarine ecosystem: ecology, threats and management (Third ed.). Oxford: Oxford University Press.

Mitchell, B. (2005). Integrated water resource management, institutional arrangements, and land-use planning. Environment and Planning A, 37(8), 1335-1352. DOI:10.1068/a37224

Morrissey, J.E. and Heidkamp, C.P. (2019) A Transitions Perspective on Coastal Sustainability, In Heidkamp and Morrissey (Eds.), Towards Coastal Resilience and Sustainability. Routledge. [In Press]. 
Morrison, T.H. (2017). Evolving polycentric governance of the Great Barrier Reef. Proceedings of the National Academy of Sciences of the United States of America, 114(15), 3013-3021. DOI:10.1073/pnas.1620830114.

Mumby, P.J., Sanchirico, J.N., Broad, K., Beck, M.W., Tyedmers, P., Morikawa, M., Okey, T.A. Crowder, L.B., Fulton, E.A., Kelso, D., Kleypas, J.A., Munch, S.B., Glynn, P., Matthews, K. and Lubchenco, J. (2017). Avoiding a crisis of motivation for ocean management under global environmental change. Global Change Biology, 23, 4483-4496.

Nayak, P.K. and Armitage, D. (2018). Social-ecological regime shifts (SERS) in coastal systems. Ocean and Coastal Management, 161, 84-95. DOI: 10.1016/j.ocecoaman.2018.04.020

Neuvonen, A., Kaskinen, T., Leppänen, J., Lähteenoja, S., Mokka, R. and Ritola, M. (2014). Low-carbon futures and sustainable lifestyles: A backcasting scenario approach. Futures, 58, 66-76. DOI:10.1016/j.futures.2014.01.004

Nevens, F., Frantzeskaki, N., Gorissen, L. and Loorbach, D. (2013), 'Urban Transition Labs: co-creating transformative action for sustainable cities', Journal of Cleaner Production 50, $111-122$

O’Brien, K. (2012). Global environmental change II From adaptation to deliberate transformation. Progress in Human Geography, 36(5), 667-676.

Olsson, P., Folke, C. and Hughes, T. P. (2008). Navigating the transition to ecosystem-based management of the Great Barrier Reef, Australia. Proceedings of the National Academy of Sciences of the United States of America, 105 (28), 9489-9494. DOI:10.1073/pnas.0706905105

Österblom, H., Gårdmark, A., Bergström, L., Müller-Karulis, B., Folke, C., Lindegren, M., Casini, M., Olsson, P., Diekmann, R., Blenckner, T., Humborg, C., Möllmann, C. and Möllmann, C. (2010). Making the ecosystem approach operational-Can regime shifts in ecological- and governance systems facilitate the transition? Marine Policy, 34(6), 12901299. DOI:10.1016/j.marpol.2010.05.007 
Ostrom, E., 2014. Collective action and the evolution of social norms. Journal of Natural Resources Policy Research, 6(4), 235-252.

Plasman, Ir. C. (2008). Implementing marine spatial planning: A policy perspective. Marine Policy, 32 (5), 811-815. DOI: 10.1016/j.marpol.2008.03.016

Roorda, C., Wittmayer, J., Henneman, P., Van Steenbergen, F., Frantzeskaki, N. and Loorbach, D. (2014). Transition management in the urban context. Guidance Manual. Rotterdam: DRIFT.

Rosen, F. and Olsson, P. (2013). Institutional entrepreneurs, global networks, and the emergence of International institutions for ecosystem-based management: The Coral Triangle Initiative. Marine Policy, 38, 195-204.

Rotmans, J. and Loorbach, D. (2010). Towards a better understanding of transitions and their governance. A systemic and reflexive approach. In: Grin, J., Rotmans, J. and Schot, J. (Eds.), Transitions to sustainable development. New directions in the study of long term transformative change. London: Routledge (pp. 105)

Rotmans, J., Kemp, R. and Van Asselt, M. (2001). More evolution than revolution: Transition management in public policy. Foresight, 3(1), 15-31. DOI:10.1108/14636680110803003

Scarff, G., Fitzsimmons, C. and Gray, T. (2015). The new mode of marine planning in the UK: Aspirations and challenges. Marine Policy, 51, 96-102.

Schneidewind, U. and Augenstein, K. (2012). Analyzing a transition to a sustainabilityoriented science system in Germany. Environmental Innovation and Societal Transitions, 3, $16-28$

Schuitmaker, T. J. (2012). Identifying and unravelling persistent problems. Technological Forecasting and Social Change, 79(6), 1021-1031. DOI:10.1016/j.techfore.2011.11.008 
Smith, H., Maes, F., Stojanovic, T. and Ballinger, R. (2011). The integration of land and marine spatial planning. Journal of Coastal Conservation, 15(2), 291-303. DOI:10.1007/s11852-010-0098-z

Smith, A. and Kern, F. (2009). The transitions storyline in Dutch environmental policy. Environmental Politics, 18(1), 78-98. DOI:10.1080/09644010802624835

Smith, A. and Raven, R. (2012). What is protective space? Reconsidering niches in transitions to sustainability. Research Policy, 41(6), 1025-1036. DOI:10.1016/j.respol.2011.12.012

Streeck, W., and Thelen, K. (2005) Institutional Changes in Advanced Political Economies. Oxford, Oxford University Press.

Stojanovic, T. and Barker, N. (2008). Improving governance through local Coastal Partnerships in the UK. Geographical Journal, 174(4), 344-360. doi:10.1111/j.1475-4959.2008.00303.x

Taleb, N.N. (2012). Antifragile: Things That Gain from Disorder. Random House, New York.

Thelen, K. (2003). How Institutions Evolve: Insights from Comparative-Historical Analysis. In: Mahoney J, Rueschemeyer D (eds) Comparative Historical Analysis in the Social Sciences. New York, Cambridge University Press.

Van der Brugge, R., Rotmans, J. and Loorbach, D. (2005). The transition in Dutch water management. Regional Environmental Change, 5(4), 164-176. DOI:10.1007/s10113-0040086-7.

Van Der Heijden, J. (2011). Institutional Layering: A Review of the Use of the Concept: Institutional Layering. Politics, 31(1), 9-18. DOI:10.1111/j.1467-9256.2010.01397.x

Van Der Voorn, T. and Quist, J. (2016). Analysing the role of visions and paradigms in purposive transitions in water management: a conceptual framework applied to the historical 
case of watershed management in the Lower Mississippi River. Exploring Transition Research as Transformative Science. 7th International Sustainability Transitions Conference, Wuppertal, Germany.

Van Raak, R. (2015). Transition policies; connecting system dynamics, governance and instruments in an application to Dutch healthcare (Doctoral thesis).

Van Rijswick, M., Edelenbos, J., Hellegers, P., Kok, M. and Kuks, S. (2014). Ten building blocks for sustainable water governance: an integrated method to assess the governance of water. Water International, 39(5), 725. DOI:10.1080/02508060.2014.951828

Verbong, G. and Loorbach, D. (2012). Governing the energy transition: reality, illusion or necessity? New York: Routledge.

Vince, J., 2015. Integrated policy approaches and policy failure: the case of Australia's Oceans Policy. Policy Sciences, 48(2), 159-180.

Wittmayer, J., Roorda, C. and van Steenbergen, F. (2014). Governing Urban Sustainability Transitions - Inspiring examples. DRIFT.

Young, O. R., Osherenko, G., Ekstrom, J., Crowder, L. B., Ogden, J., Wilson, J. A., Day, J. C., Douvere, F., Ehler, C. N., McLeod, K. L., Halpren, B. S. and Peach, R. (2007). Solving the crisis in ocean governance: place-based management of marine ecosystems, Environment, 49(4), 20-32.

Young, O.R., King, L.A. and Schroeder, H. (2008). Institutions and environmental change: principal findings, applications, and research frontiers. Cambridge, MA: MIT press. p.373 
Table 1: Review of top-cited marine management articles referencing theoretical issues relating to change

\begin{tabular}{|c|c|c|c|c|c|c|c|c|c|}
\hline Authors & Title & Year & Citations & Governance & Institutional & Legislative & Behavioural & Cultural & Political \\
\hline $\begin{array}{l}\text { Fidelman et } \\
\text { al.et al. }\end{array}$ & $\begin{array}{l}\text { Governing large-scale marine } \\
\text { commons: Contextual challenges in } \\
\text { the Coral Triangle }\end{array}$ & 2012 & 41 & $\sqrt{ }$ & $\sqrt{ }$ & $\sqrt{ }$ & & & \\
\hline $\begin{array}{l}\text { Glaser } \\
\text { al.et al. }\end{array}$ & $\begin{array}{l}\text { Whose sustainability? Top-down } \\
\text { participation and emergent rules in } \\
\text { marine protected area management in } \\
\text { Indonesia }\end{array}$ & 2010 & 36 & $\sqrt{ }$ & $\sqrt{ }$ & & $\sqrt{ }$ & $\sqrt{ }$ & \\
\hline $\begin{array}{l}\text { Rosen and } \\
\text { Olsson }\end{array}$ & $\begin{array}{l}\text { Institutional entrepreneurs, global } \\
\text { networks, and the emergence of } \\
\text { international institutions for } \\
\text { ecosystem-based management: The } \\
\text { Coral Triangle Initiative }\end{array}$ & 2013 & 29 & $\sqrt{ }$ & $\sqrt{ }$ & $\sqrt{ }$ & & & \\
\hline
\end{tabular}


Table 2: Application of the Multi-level Perspective in a marine governance context

\begin{tabular}{|c|c|c|c|}
\hline Term & Description & Example in Marine Governance & Impetus for change/ inertia \\
\hline Landscape & $\begin{array}{l}\text { Influenced by 'external' } \\
\text { forces such as changes in the } \\
\text { macro economy, politics, } \\
\text { population dynamics, natural } \\
\text { environment, culture and } \\
\text { worldviews }\end{array}$ & $\begin{array}{l}\text { Implementing EU MSP Directive in Member } \\
\text { States (MS) with a national marine spatial plan } \\
\text { due by March 2021. This should establish an } \\
\text { overarching policy for marine management. } \\
\text { Compliance with other EU Directives also } \\
\text { required on a regular basis - WFD, MSFD, } \\
\text { Floods, Natura etc. }\end{array}$ & $\begin{array}{l}\text { MS were legally required to bring into } \\
\text { force the laws, regulations and } \\
\text { administrative provisions necessary to } \\
\text { comply with the MSP Directive by } \\
\text { September 2016. However, the } \\
\text { Directive does not interfere with MS' } \\
\text { competence to design and determine } \\
\text { the format and content of marine } \\
\text { spatial plans. }\end{array}$ \\
\hline Regime & $\begin{array}{l}\text { The dominant or prevailing } \\
\text { practices, rules and patterns of } \\
\text { institutions }\end{array}$ & $\begin{array}{l}\text { In marine management, the regime relates to } \\
\text { specific arrangements of institutions, processes } \\
\text { and practices. In the UK, specific regimes were } \\
\text { established under the UK Marine and Coastal } \\
\text { Access Act, } 2009 \text { and included establishing a new } \\
\text { organisation for marine management i.e. Marine } \\
\text { Management Organisation }{ }^{4} \text { (MMO). }\end{array}$ & $\begin{array}{l}\text { Different jurisdictions have designed } \\
\text { specific arrangements for marine } \\
\text { management. Some have been more } \\
\text { innovative than others i.e. designing } \\
\text { primary legislation, establishing new } \\
\text { organisations, investing in resources, } \\
\text { multi-disciplinary skill sets etc. }\end{array}$ \\
\hline Niche & $\begin{array}{l}\text { Local experiments comprising } \\
\text { individual actors, alternative } \\
\text { technologies and local } \\
\text { practices. }\end{array}$ & $\begin{array}{l}\text { Many local marine conservation projects have } \\
\text { been established by coastal community groups. } \\
\text { Examples include the non-formal coastal } \\
\text { management examples which developed outside } \\
\text { of the main MPA programme (COREMAP) in } \\
\text { Indonesia (Glaser et al., 2010). }\end{array}$ & $\begin{array}{l}\text { There is potential for new formal rules } \\
\text { and arrangements to complement } \\
\text { locally-evolved, emergent institutions } \\
\text { as their acceptance and effectiveness is } \\
\text { likely to be much higher amongst local } \\
\text { communities. }\end{array}$ \\
\hline
\end{tabular}

${ }^{4}$ https://www.gov.uk/government/organisations/marine-management-organisation 
Table 3: Process for implementing transition management (adapted from: Roorda et al., 2014)

\section{Setting the scene for \\ transition management \\ Exploring local dynamics}

\section{Framing the transition challenge}

Envisioning integrated management

\section{Reconnecting long-term \& \\ short-term}

\section{Engaging \& anchoring}

\section{Getting into action}

\section{A transition team is formed to drive the process and embed it in the local context.}

The transition team starts to explore the area's dynamics, conducting interviews and doing desk research, and working towards a system analysis and actor analysis.

Based on the actor analysis, a diverse group of change agents is invited to engage in a series of meetings as a transition arena group.

The change agents first explore the transition challenges and create a shared problem framing.

Subsequently, they exchange and elaborate perspectives on a possible future, thereby creating visionary images for the future of the estuary or coastal ecosystem.

As a final step in the transition arena setting, the change agents elaborate transition pathways, indicating fundamental changes and corresponding actions needed to reach the envisioned future.

The ideas brought forward by the transition arena are summarised and published in a transition agenda.

Actions are undertaken to make the transition agenda public and give others a chance to adopt and adapt it, and relate it to their own agenda and practices.

Transition experiments, radical short-term actions in line with the transition agenda, are initiated or adapted. Through these actions, more actors become engaged. Insights from these experiments can be taken to a more strategic level. 
Table 4: Overview of the recommended stages and actions in a Transition Management approach for marine governance transformation. Adapted from Roorda et al., 2014.

\begin{tabular}{|c|c|c|}
\hline \multicolumn{3}{|c|}{ Potential Short-term Transition Phase (0-3years) } \\
\hline Multi-stage & Recommended steps & Key actions \\
\hline $\begin{array}{l}\text { 1. Forming a } \\
\text { Transition Arena }\end{array}$ & $\begin{array}{ll}\text { - } & \text { Establishing a Transition Team } \\
\text { - } & \text { Setting the scene } \\
\text { - } & \text { System and actor analysis } \\
\text { - } & \text { Estection of frontrunners Transition Arena } \\
\text { - } & \text { Problem framing } \\
\text { - } & \text { Framing challenges }\end{array}$ & $\begin{array}{l}\text { - } \text { An initiating/sponsoring agency forms Transition Team } \\
\text { - } \quad \text { Issues to be addressed are specified } \\
\text { - } \quad \text { Draft term goals are agreed } \\
\text { - } \quad \text { Delineate the system boundaries in space, time, themes } \\
\text { - } \quad \text { Define system characteristics } \\
\text { - } \quad \text { Identify frond analyse data } \\
\text { - } \quad \text { Sesearch, interviers or and panticipative workshops } \\
\text { - } \quad \text { Arrange of frontrunners for Transition Arena } \\
\quad \text { challenges and frame problems }\end{array}$ \\
\hline 2. Envisioning & $\begin{array}{l}\text { - } \quad \text { Sharing a vision } \\
\text { - } \text { Agenda building } \\
\text { - Transition pathways } \\
\text { - Transition agenda } \\
\text { - Engaging and anchoring the } \\
\quad \text { public }\end{array}$ & $\begin{array}{l}\text { - } \quad \text { Exchange perspectives on the future } \\
\text { - } \quad \text { Formulate guiding integration principles } \\
\text { - } \quad \text { Create visionary images } \\
\text { - Use of Backe vision } \\
\text { - Identify short-term actions } \\
\text { - } \quad \text { Consolidate the transition agenda }\end{array}$ \\
\hline \multicolumn{3}{|c|}{ Potential Medium-term Transition Phase (3-10 years) } \\
\hline $\begin{array}{l}3 . \quad \text { Steering } \\
\text { process and } \\
\text { experimentation }\end{array}$ & $\begin{array}{l}\text { - } \quad \text { Engaging and Anchoring } \\
\text { - Transition experiments } \\
\text { Examples: } \\
\text { - Record and map uses } \\
\text { - } \quad \text { Scope pressures, impacts } \\
\text { - } \quad \text { Examine interconnections } \\
\text { - Develop indicators and } \\
\text { determine trends } \\
\text { - Consider risk analysis } \\
\text { Radical short-term actions } \\
\text { - Develop sustainability tools for } \\
\text { - the coast. } \quad \text { Extensive and creative } \\
\text { - } \text { participation forums/ platforms } \\
\text { Innovative management } \\
\text { strategies and options } \\
\text { Assist plan/ programme- } \\
\text { making ilot changes to influence } \\
\text { legislation and governance }\end{array}$ & $\begin{array}{l}\text { - Kick-start the process with an event } \\
\text { - Undertake activities to support initiatives } \\
\text { - Setting up initiatives: Specific actions of the transition } \\
\text { agenda are selected and progressed } \\
\text { - Establish working groups where required to work on } \\
\text { initiatives } \\
\text { - Supporting initiatives: A co-ordinating team can assist or } \\
\text { facilitate the work of the working groups and other } \\
\text { sustainability initiatives by mapping relevant actors, } \\
\text { creating a network, searching for funds and playing an } \\
\text { active role in the project themselves. }\end{array}$ \\
\hline \multicolumn{3}{|c|}{ Potential Longer-term Transition Phase (10-25yrs) } \\
\hline $\begin{array}{l}\text { 4. Monitoring, } \\
\text { evaluation and } \\
\text { reflexivity }\end{array}$ & $\begin{array}{ll}\text { - } & \text { Implementation } \\
\text { - } & \text { Learning } \\
\text { - } & \text { Reflexive governance } \\
\text { - } & \text { Visioning of system transition } \\
\text { - } & \text { Large-scale institutional change }\end{array}$ & $\begin{array}{l}\text { - } \quad \text { Examine achievements } \\
\text { - Monitor and evaluate transition processes and actors } \\
\text { - Reflect on lessons learned } \\
\text { - Radical suggestions for large-scale institutional change } \\
\text { - Major shifts in dominant structures, cultures and } \\
\text { practices } \\
\text { - }\end{array}$ \\
\hline
\end{tabular}




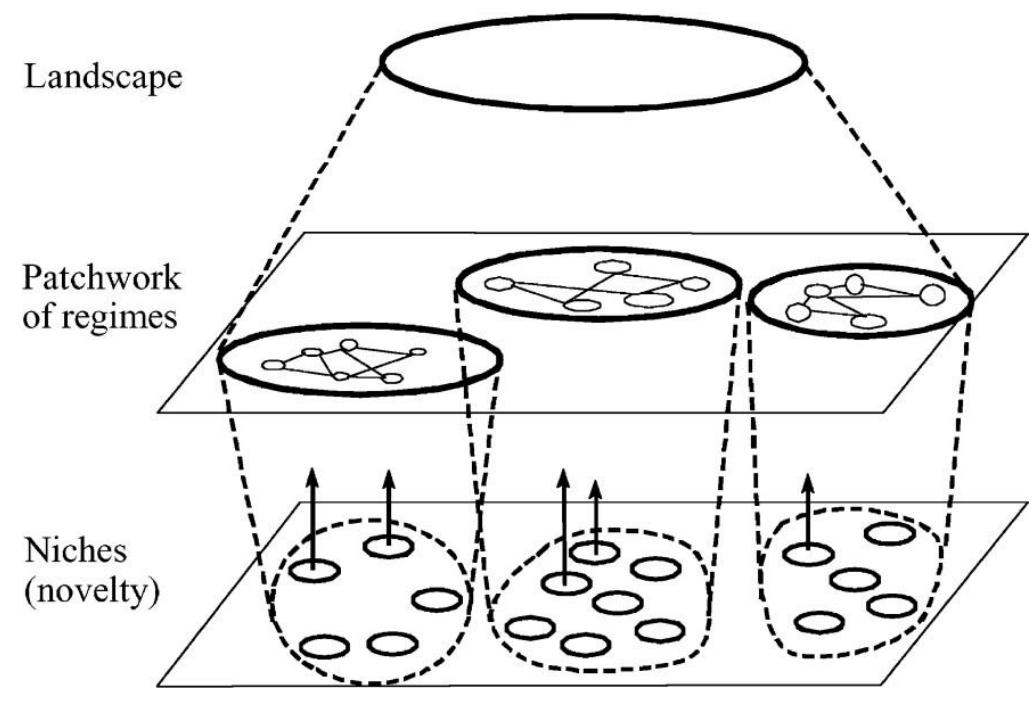

Figure 1: Diagrammatic representation of the multi-level concept in transition studies. Source: Geels, 2002, p.1261. 


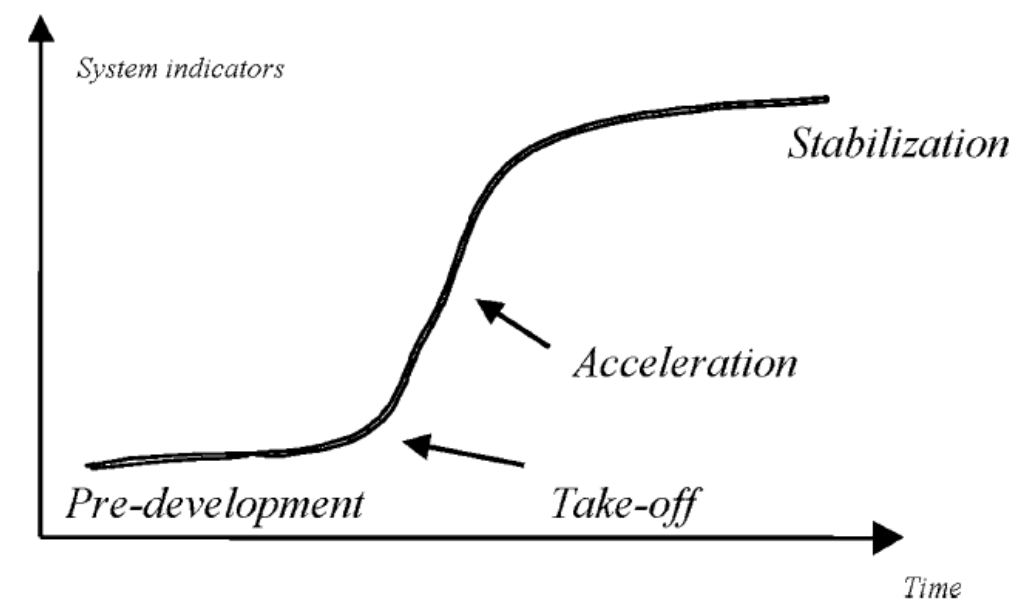

Figure 2: Multi-stage concept within transition theory. Source: Van Der Brugge et al., 2005, $p$. 166. 


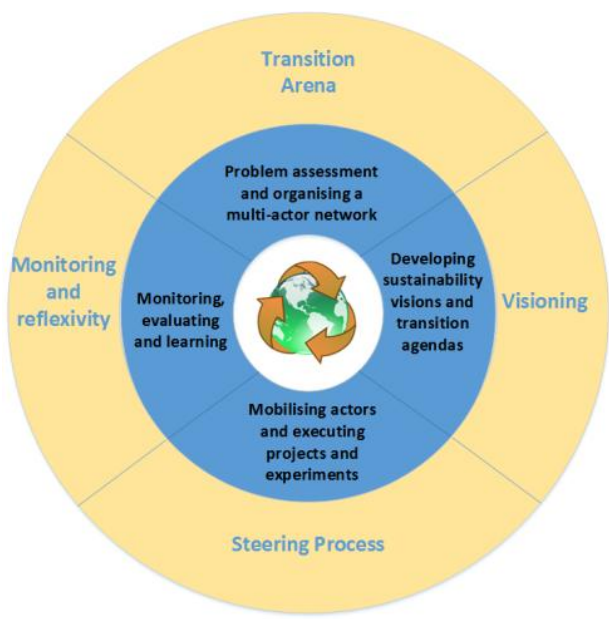

Figure 3: Transition Management Cycle. Based on an adaptation by Van Der Brugge et al., 2005; Loorbach and Rotmans, 2010 


\section{Appendix A}

\section{Summary review of top 50 cited marine-related articles in Scopus database}

\begin{tabular}{|c|c|c|c|c|c|}
\hline Authors & Title & Year & DOI & $\begin{array}{l}\text { No. } \\
\text { citations }\end{array}$ & $\begin{array}{l}\text { 'Transformative } \\
\text { Change' reference } \\
\text { - Yes/No }\end{array}$ \\
\hline Douvere F. & $\begin{array}{l}\text { The importance of marine spatial planning in advancing ecosystem-based } \\
\text { sea use management }\end{array}$ & 2008 & $\frac{\underline{\text { https://doi.org/1 }}}{\underline{\text { 0.1016/j.marpol. }}}$ & 340 & $\mathrm{~N}$ \\
\hline $\begin{array}{l}\text { Crowder and } \\
\text { Norse }\end{array}$ & $\begin{array}{l}\text { Essential ecological insights for marine ecosystem-based management and } \\
\text { marine spatial planning }\end{array}$ & 2008 & $\begin{array}{l}\text { https://doi.org/1 } \\
\underline{0.1016 / \text { j.marpol. }} \\
\underline{2008.03 .012}\end{array}$ & 200 & $\mathrm{~N}$ \\
\hline Foley et al. & Guiding ecological principles for marine spatial planning & 2010 & $\begin{array}{l}\text { https://doi.org/1 } \\
\underline{0.1016 / \text { j.marpol. }} \\
\underline{2010.02 .001}\end{array}$ & 186 & $\mathrm{~N}$ \\
\hline $\begin{array}{l}\text { Pomeroy and } \\
\text { Douvere }\end{array}$ & The engagement of stakeholders in the marine spatial planning process & 2008 & $\begin{array}{l}\underline{\text { https://doi.org/1 }} \\
\underline{\underline{0.1016 / \text { j.marpol. }}} \\
\underline{2008.03 .017}\end{array}$ & 174 & $\mathrm{~N}$ \\
\hline Agardy et al. & $\begin{array}{l}\text { Mind the gap: Addressing the shortcomings of marine protected areas } \\
\text { through large scale marine spatial planning }\end{array}$ & 2011 & $\begin{array}{l}\underline{\text { https://doi.org/1 }} \\
\underline{0.1016 / \text { j.marpol. }} \\
\underline{2010.10 .006}\end{array}$ & 170 & $\mathrm{~N}$ \\
\hline $\begin{array}{l}\text { Gilliland and } \\
\text { Laffoley }\end{array}$ & $\begin{array}{l}\text { Key elements and steps in the process of developing ecosystem-based } \\
\text { marine spatial planning }\end{array}$ & 2008 & $\begin{array}{l}\underline{\text { https://doi.org/1 }} \\
\underline{\underline{0.1016 / \text { j.marpol. }}} \\
\underline{2008.03 .022}\end{array}$ & 118 & $\mathrm{~N}$ \\
\hline $\begin{array}{l}\text { St. Martin and } \\
\text { Hall-Arber }\end{array}$ & $\begin{array}{l}\text { The missing layer: Geo-technologies, communities, and implications for } \\
\text { marine spatial planning }\end{array}$ & 2008 & $\frac{\underline{\text { https://doi.org/1 }}}{\underline{\underline{0.1016 / j . m a r p o l} .}}$ & 103 & $\mathrm{~N}$ \\
\hline Douvere et al. & $\begin{array}{l}\text { The role of marine spatial planning in sea use management: The Belgian } \\
\text { case }\end{array}$ & 2007 & $\begin{array}{l}\underline{\text { https://doi.org/1 }} \\
\underline{\underline{0.1016 / j . m a r p o l} .} \\
\underline{2006.07 .003}\end{array}$ & 103 & $\mathrm{~N}$ \\
\hline Day J. & $\begin{array}{l}\text { The need and practice of monitoring, evaluating and adapting marine } \\
\text { planning and management-lessons from the Great Barrier Reef }\end{array}$ & 2008 & $\begin{array}{l}\underline{\mathrm{https}: / / \text { doi.org/1 }} \\
\underline{\underline{0.1016 / \mathrm{j} . \mathrm{marpol}} .} \\
\underline{2008.03 .023} \\
\end{array}$ & 90 & $\mathrm{~N}$ \\
\hline
\end{tabular}




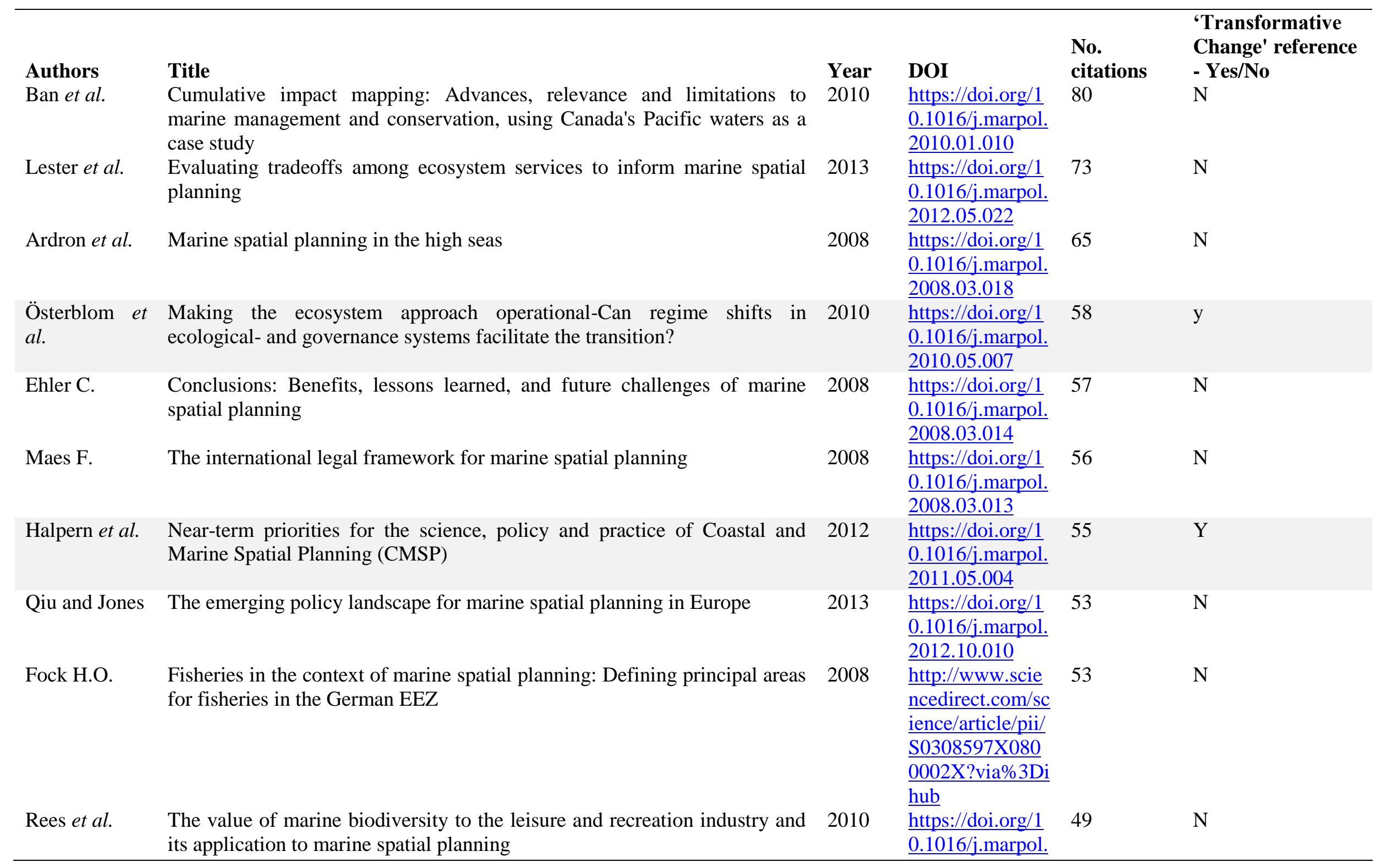




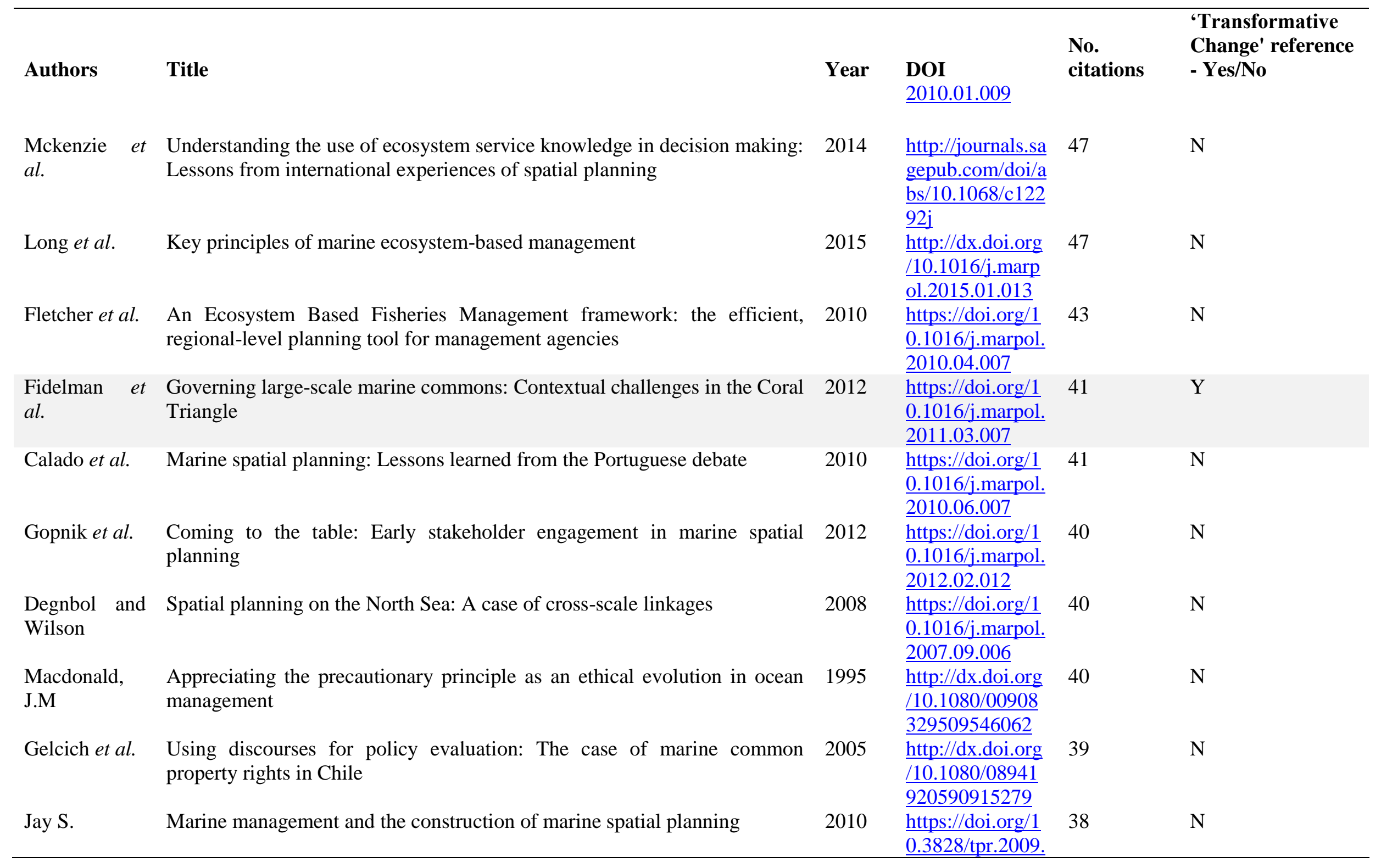




\begin{tabular}{|c|c|c|c|c|c|}
\hline Authors & Title & Year & $\begin{array}{l}\text { DOI } \\
\underline{33}\end{array}$ & $\begin{array}{l}\text { No. } \\
\text { citations }\end{array}$ & $\begin{array}{l}\text { 'Transformative } \\
\text { Change' reference } \\
\text { - Yes/No }\end{array}$ \\
\hline $\begin{array}{l}\text { Ritchie and } \\
\text { Ellis }\end{array}$ & $\begin{array}{l}\text { 'A system that works for the sea'? Exploring stakeholder engagement in } \\
\text { marine spatial planning }\end{array}$ & 2010 & $\begin{array}{l}\underline{\mathrm{http}: / / \mathrm{dx} . \text { doi.org }} \\
\underline{110.1080 / 09640} \\
\underline{568.2010 .48810} \\
\underline{0}\end{array}$ & 37 & $\mathrm{~N}$ \\
\hline Glaser et al. & $\begin{array}{l}\text { Whose sustainability? Top-down participation and emergent rules in } \\
\text { marine protected area management in Indonesia }\end{array}$ & 2010 & $\begin{array}{l}\frac{\text { https://doi.org/1 }}{\text { 0.1016/j.marpol. }} \\
\underline{2010.04 .006}\end{array}$ & 36 & $\mathrm{Y}$ \\
\hline $\begin{array}{l}\text { Stojanovic } \\
\text { and Barker }\end{array}$ & Improving governance through local Coastal Partnerships in the UK & 2008 & $\begin{array}{l}\frac{\mathrm{http} / / / \mathrm{dx} \cdot \text { doi.org }}{/ 10.1111 / \mathrm{j} \cdot 1475-} \\
\text { 3959.2008.0030 } \\
\text {.x }\end{array}$ & 36 & $\mathrm{~N}$ \\
\hline $\begin{array}{l}\text { Suárez de } \\
\text { Vivero } \text { et al. }\end{array}$ & $\begin{array}{l}\text { Geopolitical factors of maritime policies and marine spatial planning: State, } \\
\text { regions, and geographical planning scope }\end{array}$ & 2009 & $\frac{\underline{\mathrm{https}: / / \text { doi.org/1 }}}{\underline{\underline{0.1016 / \mathrm{j} . \mathrm{marppol}}}}$ & 34 & $\mathrm{~N}$ \\
\hline Dunn et al. & $\begin{array}{l}\text { The Convention on Biological Diversity's Ecologically or Biologically } \\
\text { Significant Areas: Origins, development, and current status }\end{array}$ & 2014 & $\frac{\underline{\text { https://doi.org/1 }}}{\underline{0.1016 / \text { j.marpol. }}}$ & 33 & $\mathrm{~N}$ \\
\hline Plasman Ir.C. & Implementing marine spatial planning: A policy perspective & 2008 & $\begin{array}{l}\text { https://doi.org/1 } \\
\underline{0.1016 / \text { j.marpol. }} \\
\underline{2008.03 .016}\end{array}$ & 33 & $\mathrm{~N}$ \\
\hline
\end{tabular}




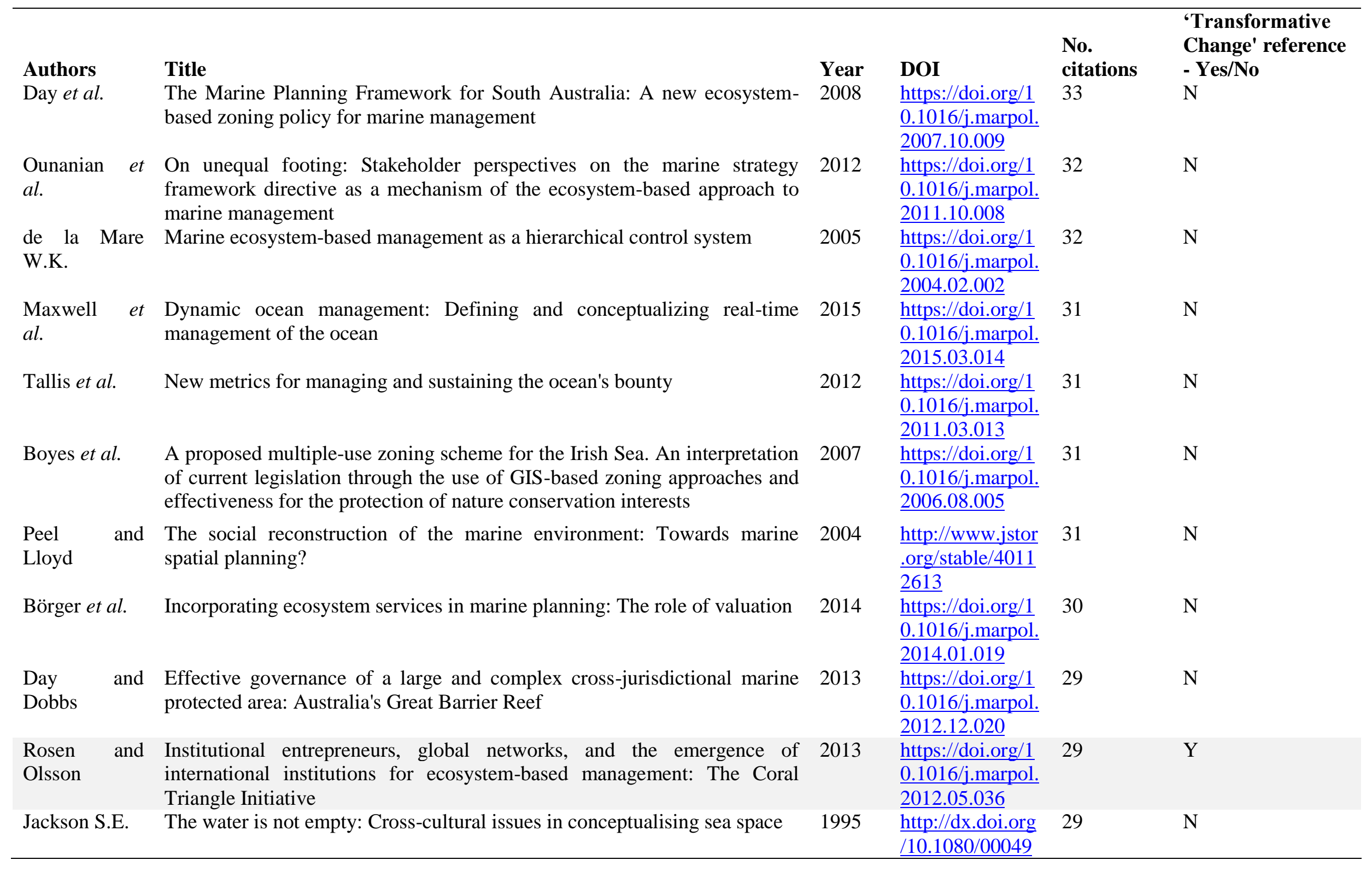




\begin{tabular}{|c|c|c|c|c|c|}
\hline Authors & Title & Year & $\begin{array}{l}\text { DOI } \\
\underline{189508703133}\end{array}$ & $\begin{array}{l}\text { No. } \\
\text { citations }\end{array}$ & $\begin{array}{l}\text { 'Transformative } \\
\text { Change' reference } \\
\text { - Yes/No }\end{array}$ \\
\hline
\end{tabular}




\section{Appendix References:}

Agardy, T., Di Sciara, G.N. and Christie, P. (2011). Mind the gap: Addressing the shortcomings of marine protected areas through large scale marine spatial planning. Marine Policy, 35(2), 226-232. DOI: 10.1016/j.marpol.2010.10.006

Ardron, J., Gjerde, K., Pullen, S. and Tilot, V. (2008). Marine spatial planning in the high seas. Marine Policy, 32(5), 832-839. DOI: 10.1016/j.marpol.2008.03.018

Ban, N.C., Alidina, H.M. and Ardron, J.A. (2010). Cumulative impact mapping: Advances, relevance and limitations to marine management and conservation, using Canada's Pacific waters as a case study. Marine Policy, 34(5), 876-886. DOI: 10.1016/j.marpol.2010.01.010

Börger, T., Beaumont, N.J., Pendleton, L., Boyle, K.J., Cooper, P., Fletcher, S., Haab, T., Hanemann, M., Hooper, T.L., Hussain, S.S., Portela, R., Stithou, M., Stockill, J., Taylor, T. and Austen, M.C. (2014). Incorporating ecosystem services in marine planning: The role of valuation. Marine Policy, 46, 161-170. DOI: 10.1016/j.marpol.2014.01.019

Boyes, S.J., Elliott, M., Thomson, S.M., Atkins, S. and Gilliland, P. (2007). A proposed multiple-use zoning scheme for the Irish Sea. An interpretation of current legislation through the use of GIS-based zoning approaches and effectiveness for the protection of nature conservation interests. Marine Policy, 31(3), 287-298. DOI: 10.1016/j.marpol.2006.08.005

Calado, H., Ng, K., Johnson, D., Sousa, L., Phillips, M. and Alves, F. (2010). Marine spatial planning: Lessons learned from the Portuguese debate. Marine Policy, 34(6), 1341-1349. DOI: 10.1016/j.marpol.2010.06.007 
Crowder, L. and Norse, E. (2008). Essential ecological insights for marine ecosystem-based management and marine spatial planning. Marine Policy, 32(5), 772-778. DOI: 10.1016/j.marpol.2008.03.012

Dalton, T., Thompson, R. and Jin, D. (2010). Mapping human dimensions in marine spatial planning and management: An example from Narragansett Bay, Rhode Island. Marine Policy, 34(2), 309-319. DOI: 10.1016/j.marpol.2009.08.001

Day, J. (2008). The need and practice of monitoring, evaluating and adapting marine planning and management-lessons from the Great Barrier Reef. Marine Policy, 32(5), 823831. DOI: 10.1016/j.marpol.2008.03.023

Day, J.C. and Dobbs, K. (2013). Effective governance of a large and complex crossjurisdictional marine protected area: Australia's Great Barrier Reef. Marine Policy, 41, 14-24. DOI: 10.1016/j.marpol.2012.12.020

Day, V., Paxinos, R., Emmett, J., Wright, A. and Goecker, M. (2008). The Marine Planning Framework for South Australia: A new ecosystem-based zoning policy for marine management. Marine Policy, 32(4), 535-543. DOI: 10.1016/j.marpol.2007.10.009

De La Mare, W.K. (2005). Marine ecosystem-based management as a hierarchical control system. Marine Policy, 29(1), 57-68. DOI: 10.1016/j.marpol.2004.02.002 
Degnbol, D. and Wilson, D.C. (2008). Spatial planning on the North Sea: A case of crossscale linkages. Marine Policy, 32(2), 189-200. DOI: 10.1016/j.marpol.2007.09.006

Douvere, F. (2008). The importance of marine spatial planning in advancing ecosystem-based sea use management. Marine Policy, 32(5), 762-771. DOI: 10.1016/j.marpol.2008.03.021. DOI: 10.1016/j.marpol.2008.03.021

Douvere, F., Maes, F., Vanhulle, A. and Schrijvers, J. (2007). The role of marine spatial planning in sea use management: The Belgian case. Marine Policy, 31(2), 182-191. DOI: 10.1016/j.marpol.2006.07.003

Dunn, D.C., Ardron, J., Bax, N., Bernal, P., Cleary, J., Cresswell, I., Donnelly, B., Dunstan, P., Gjerde, K., Johnson, D., Kaschner, K., Lascelles, B., Rice, J., Von Nordheim, H., Wood, L. and Halpin, P.N. (2014). The Convention on Biological Diversity's Ecologically or Biologically Significant Areas: Origins, development, and current status. Marine Policy, 49, 137-145. DOI: 10.1016/j.marpol.2013.12.002

Ehler, C. (2008). Conclusions: Benefits, lessons learned, and future challenges of marine spatial planning. Marine Policy, 32(5), 840-843. DOI: 10.1016/j.marpol.2008.03.014

Fidelman, P., Evans, L., Fabinyi, M., Foale, S., Cinner, J. and Rosen, F. (2012). Governing large-scale marine commons: Contextual challenges in the Coral Triangle. Marine Policy, 36(1), 42-53. DOI: 10.1016/j.marpol.2011.03.007 
Fletcher, W.J., Shaw, J., Metcalf, S.J. and Gaughan, D.J. (2010). An Ecosystem Based Fisheries Management framework: the efficient, regional-level planning tool for management agencies. Marine Policy, 34(6), 1226-1238. DOI: 10.1016/j.marpol.2010.04.007

Fock, H.O. (2008). Fisheries in the context of marine spatial planning: Defining principal areas for fisheries in the German EEZ. Marine Policy, 32(4), 728-739. DOI: 10.1016/j.marpol.2007.12.010

Foley, M.M., Halpern, B.S., Micheli, F., Armsby, M.H., Caldwell, M.R., Crain, C.M., Prahler, E., Rohr, N., Sivas, D., Beck, M.W., Carr, M.H., Crowder, L.B., Emmett Duffy, J., Hacker, S.D., McLeod, K.L., Palumbi, S.R., Peterson, C.H., Regan, H.M., Ruckelshaus, M.H., Sandifer, P.A. and Steneck, R.S. (2010). Guiding ecological principles for marine spatial planning. Marine Policy, 34(5), 955-966. DOI: 10.1016/j.marpol.2010.02.001

Gelcich, S., Edwards-Jones, G., Kaiser, M.J. and Watson, E. (2005). Using discourses for policy evaluation: The case of marine common property rights in Chile. Society and Natural Resources, 18(4), 377-391. DOI: 10.1080/08914920590915279

Gilliland, P.M. and Laffoley, D. (2008). Key elements and steps in the process of developing ecosystem-based marine spatial planning. Marine Policy, 32(5), 787-796. DOI: 10.1016/j.marpol.2008.03.022

Glaser, M., Baitoningsih, W., Ferse, S.C.A., Neil, M. and Deswandi, R. (2010). Whose sustainability? Top-down participation and emergent rules in marine protected area 
management in Indonesia. Marine Policy, 34(6), 1215-1225. DOI: 10.1016/j.marpol.2010.04.006

Gopnik, M., Fieseler, C., Cantral, L., McClellan, K., Pendleton, L. and Crowder, L. (2012). Coming to the table: Early stakeholder engagement in marine spatial planning. Marine Policy, 36(5), 1139-1149. DOI: 10.1016/j.marpol.2012.02.012

Halpern, B.S., Diamond, J., Gaines, S., Gelcich, S., Gleason, M., Jennings, S., Lester, S., Mace, A., McCook, L., Mcleod, K., Napoli, N., Rawson, K., Rice, J., Rosenberg, A., Ruckelshaus, M., Saier, B., Sandifer, P., Scholz, A. and Zivian, A. (2012). Near-term priorities for the science, policy and practice of Coastal and Marine Spatial Planning (CMSP). Marine Policy, 36(1), 198-205. DOI: 10.1016/j.marpol.2011.05.004

Hind, E.J., Hiponia, M.C. and Gray, T.S. (2010). From community-based to centralised national management-A wrong turning for the governance of the marine protected area in Apo Island, Philippines? Marine Policy, 34(1), 54-62. DOI: 10.1016/j.marpol.2009.04.011

Jackson, S.E. (1995). The water is not empty: Cross-cultural issues in conceptualising sea space. Australian Geographer, 26(1), 87-96. DOI: 10.1080/00049189508703133

Jay, S. (2010). Marine management and the construction of marine spatial planning. Town Planning Review, 81(2), 173-192. DOI: 10.3828/tpr.2009.33 
Lester, S.E., Costello, C., Halpern, B.S., Gaines, S.D., White, C. and Barth, J.A. (2013). Evaluating tradeoffs among ecosystem services to inform marine spatial planning. Marine Policy, 38, 80-89. DOI: 10.1016/j.marpol.2012.05.022

Long, R.D., Charles, A. and Stephenson, R.L. (2015). Key principles of marine ecosystembased management. Marine Policy, 57, 53-60. DOI: 10.1016/j.marpol.2015.01.013

MacDonald, J.M. (1995). Appreciating the precautionary principle as an ethical evolution in ocean management. Ocean Development and International Law, 26(3), 255-286. DOI: $10.1080 / 00908329509546062$

Maes, F. (2008). The international legal framework for marine spatial planning. Marine Policy, 32(5), 797-810. DOI: 10.1016/j.marpol.2008.03.013

Maxwell, S.M., Hazen, E.L., Lewison, R.L., Dunn, D.C., Bailey, H., Bograd, S.J., Briscoe, D.K., Fossette, S., Hobday, A.J., Bennett, M., Benson, S., Caldwell, M.R., Costa, D.P., Dewar, H., Eguchi, T., Hazen, L., Kohin, S., Sippel, T. and Crowder, L.B. (2015). Dynamic ocean management: Defining and conceptualizing real-time management of the ocean. Marine Policy, 58, 42-50. DOI: 10.1016/j.marpol.2015.03.014

McKenzie, E., Posner, S., Tillmann, P., Bernhardt, J.R., Howard, K. and Rosenthal, A. (2014). Understanding the use of ecosystem service knowledge in decision making: Lessons from international experiences of spatial planning. Environment and Planning $C$ : Government and Policy, 32(2), 320-340. DOI: 10.1068/c12292j 
Österblom, H., Gårdmark, A., Bergström, L., Müller-Karulis, B., Folke, C., Lindegren, M., Casini, M., Olsson, P., Diekmann, R., Blenckner, T., Humborg, C. and Möllmann, C. (2010). Making the ecosystem approach operational-Can regime shifts in ecological- and governance systems facilitate the transition? Marine Policy, 34(6), 1290-1299. DOI: 10.1016/j.marpol.2010.05.007

Ounanian, K., Delaney, A., Raakjær, J. and Ramirez-Monsalve, P. (2012). On unequal footing: Stakeholder perspectives on the marine strategy framework directive as a mechanism of the ecosystem-based approach to marine management. Marine Policy, 36(3), 658-666. DOI: 10.1016/j.marpol.2011.10.008

Peel, D. and Lloyd, M.G. (2004). The social reconstruction of the marine environment: Towards marine spatial planning? Town Planning Review, 75(3), 359-378. http://www.jstor.org/stable/40112613

Plasman, I.C. (2008). Implementing marine spatial planning: A policy perspective. Marine Policy, 32(5), 811-815. DOI: 10.1016/j.marpol.2008.03.016

Pomeroy, R. and Douvere, F. (2008). The engagement of stakeholders in the marine spatial planning process. Marine Policy, 32(5), 816-822. DOI: 10.1016/j.marpol.2008.03.017

Qiu, W. and Jones, P.J.S. (2013). The emerging policy landscape for marine spatial planning in Europe. Marine Policy, 39(1), 182-190. DOI: 10.1016/j.marpol.2012.10.010 
Rees, S.E., Rodwell, L.D., Attrill, M.J., Austen, M.C. and Mangi, S.C. (2010). The value of marine biodiversity to the leisure and recreation industry and its application to marine spatial planning. Marine Policy, 34(5), 868-875. DOI: 10.1016/j.marpol.2010.01.009

Ritchie, H. and Ellis, G. (2010). 'A system that works for the sea'? Exploring stakeholder engagement in marine spatial planning. Journal of Environmental Planning and Management, 53(6), 701-723. DOI: 10.1080/09640568.2010.488100

Rosen, F. and Olsson, P. (2013). Institutional entrepreneurs, global networks, and the emergence of international institutions for ecosystem-based management: The Coral Triangle Initiative. Marine Policy, 38, 195-204. DOI: 10.1016/j.marpol.2012.05.036

St. Martin, K. and Hall-Arber, M. (2008). The missing layer: Geo-technologies, communities, and implications for marine spatial planning. Marine Policy, 32(5), 779-786. DOI: 10.1016/j.marpol.2008.03.015

Stelzenmüller, V., Breen, P., Stamford, T., Thomsen, F., Badalamenti, F., Borja, T., BuhlMortensen, L., Carlstöm, J., D'anna, G., Dankers, N., DeGraer, S., Dujin, M., Fiorentino, F., Galparsoro, I., Giakoumi, S., Gristina, M., Johnson, K., Jones, P.J.S., Katsanevakis, S., Knittweis, L., Kyriazi, Z., Pipitone, C., Piwowarczyk, J., Rabaut, M., Sørensen, T.K., Van Dalfsen, J., Vassilopoulou, V., Vega Fernández, T., Vincx, M., Vöge, S., Weber, A., Wijkmark, N., Jak, R., Qiu, W. and Ter Hofstede, R. (2013). Monitoring and evaluation of spatially managed areas: A generic framework for implementation of ecosystem based marine management and its application. Marine Policy, 37(1), 149-164. DOI: 10.1016/j.marpol.2012.04.012 
Stelzenmüller, V., Lee, J., South, A., Foden, J. and Rogers, S.I. (2013). Practical tools to support marine spatial planning: A review and some prototype tools. Marine Policy, 38, 214227. DOI: $10.1016 /$ j.marpol.2012.05.038

Stojanovic, T. and Barker, N. (2008). Improving governance through local Coastal Partnerships in the UK. Geographical Journal, 174(4), 344-360. DOI: 10.1111/j.14754959.2008.00303.x

Suárez De Vivero, J.L., Rodríguez Mateos, J.C. and Florido Del Corral, D. (2009). Geopolitical factors of maritime policies and marine spatial planning: State, regions, and geographical planning scope. Marine Policy, 33(4), 624-634. DOI: 10.1016/j.marpol.2008.12.010

Tallis, H., Lester, S.E., Ruckelshaus, M., Plummer, M., McLeod, K., Guerry, A., Andelman, S., Caldwell, M.R., Conte, M., Copps, S., Fox, D., Fujita, R., Gaines, S.D., Gelfenbaum, G., Gold, B., Kareiva, P., Kim, C., Lee, K., Papenfus, M., Redman, S., Silliman, B., Wainger, L. and White, C. (2012). New metrics for managing and sustaining the ocean's bounty. Marine Policy, 36(1), 303-306. DOI: 10.1016/j.marpol.2011.03.013

Weiss, K., Hamann, M., Kinney, M. and Marsh, H. (2012). Knowledge exchange and policy influence in a marine resource governance network. Global Environmental Change, 22(1), 178-188. DOI: 10.1016/j.gloenvcha.2011.09.007 